\title{
Tropical dry forests
}

\section{The state of global knowledge and recommendations for future research}

Reuben Blackie, Cristina Baldauf, Denis Gautier, Davidson Gumbo,

Habtemariam Kassa, N. Parthasarathy, Fiona Paumgarten, Phosiso Sola,

Sandeep Pulla, Patrick Waeber and Terry Sunderland 



\title{
Tropical dry forests \\ The state of global knowledge and recommendations for future research
}

\author{
Reuben Blackie \\ Center for International Forestry Research (CIFOR) \\ Cristina Baldauf \\ Universidade Federal Rural do Semiárido (UFERSA) \\ Denis Gautier \\ CIRAD-BSEF \\ CIFOR \\ Davidson Gumbo \\ CIFOR \\ Habtemariam Kassa \\ CIFOR \\ N. Parthasarathy \\ Pondicherry University \\ Fiona Paumgarten \\ University of Witwatersrand \\ Phosiso Sola \\ CIFOR \\ Sandeep Pulla \\ Indian Institute of Science \\ Patrick Waeber \\ Swiss Federal Institute of Technology Zurich \\ Terry Sunderland \\ CIFOR
}


๑ 2014 Center for International Forestry Research

Content in this publication is licensed under a Creative Commons Attribution-NonCommercial-NoDerivs 3.0 Unported License http://creativecommons.org/licenses/by-nc-nd/3.0/

Blackie R, Baldauf C, Gautier D, Gumbo D, Kassa H, Parthasarathy N, Paumgarten F, Sola P, Pulla S, Waeber P and Sunderland T. 2014. Tropical dry forests: The state of global knowledge and recommendations for future research. Discussion Paper. Bogor, Indonesia: CIFOR.

Photo by Ollivier Girard/CIFOR.

Landscape of Gebe Valley Woodland, Ethiopia.

\section{CIFOR}

Jl. CIFOR, Situ Gede

Bogor Barat 16115

Indonesia

$\mathrm{T}+62(251) 8622-622$

$F+62(251) 8622-100$

E cifor@cgiar.org

\section{cifor.org}

We would like to thank all donors who supported this research through their contributions to the CGIAR Fund. For a list of Fund donors please see: https://www.cgiarfund.org/FundDonors

Any views expressed in this book are those of the authors. They do not necessarily represent the views of CIFOR, the editors, the authors' institutions, the financial sponsors or the reviewers. 


\section{Table of contents}

1 Introduction 1

2 Why focus on dry forests? 11

3 Building on the past 2

4 Global dry forests $\quad 3$

5 Summary of research priorities $\quad 4$

6 The regions at a glance: Where are the research gaps?

6.1 Latin America and Caribbean 4

6.2 Africa 5

6.3 Asia 2.5

6.4 Pacific $\quad 6$

7 The state of dry forest knowledge by theme $\quad 6$

7.1 Theme 1: Climate change adaptation and mitigation 6

7.2 Theme 2: Food security and livelihoods $\quad 8$

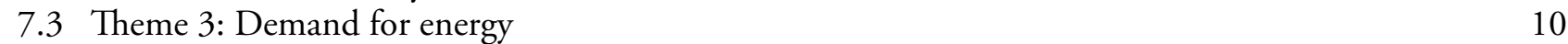

7.4 Theme 4: Sustainable management of dry forests 11

7.5 Theme 5: Policies and institutional support for sustainable management 12

8 Conclusion $\quad 14$

9 References $\quad 15$

Annexes

1 Potential research questions by theme 25

2 Studies with merit for replication elsewhere $\quad 29$

3 Map of global ecological zones (GEZ) showing the worldwide distribution of dry forests 30 



\section{Introduction}

This discussion paper assesses the state of knowledge on tropical dry forests ${ }^{1}$ as it relates to CIFOR's strategy and identifies research opportunities that align with CIFOR's strategic goals. Over the past two decades, CIFOR has accumulated a substantial body of work on dry forests, with a particular focus on African dry forests. This paper is intended to build on that work, by gathering wider research from around the world, as CIFOR seeks to widen the geographic scope of its research on dry forests. The present assessment explores five themes: climate change mitigation and adaptation; food security and livelihoods; demand for energy; sustainable management of dry forests; and policies and institutional support for sustainable management. These themes emerged as priority areas during discussions on dry forest research priorities held at CIFOR's Dry Forests Symposium in South Africa in $2011^{2}$. Research on these themes should be considered a priority, given the importance of dry forests to people and ecosystems around the world and the threats posed to them.

Generally, the review reveals a clear need for an increase in the following:

- Up-to-date information on deforestation in African dry forests

- Livelihoods-based research in Latin America

- Research across the entire portfolio in Asia, the Pacific and the Caribbean.

For specific research topics, the assessment finds the following:

- Research on climate change and carbon is advanced for the dry forests of Latin America and parts of Africa, but severely lacking for other regions.

- Food security and livelihoods have been well studied in parts of Africa, but in all other regions the role of dry forests in food security is underresearched, particularly in the area of direct provisioning.

- Africa is well represented in research into energy supply and demand (particularly woodfuel and charcoal, but increasingly biofuels as well).

1 In this paper, the term "dry forest" is used to refer to forest that meets the FAO (2000) definition of tropical dry forest, outlined in Section 4 below.

2 New research agenda for dry forests defined at Durban, http://blog.cifor.org/5614/new-research-agenda-for-africas-dryforests-defined-at-durban/
Latin America has been the subject of extensive biofuels research.

- Novel management institutions, such as community forestry, have received research attention in the dry forests of Latin America and Africa but not those of India, where research of this nature has focused on other environments.

- Greater research on sustainable management of dry forests specifically is required in all regions, as is analysis of forestry policy and policy in other sectors that affects dry forests.

CIFOR has used recent high-profile events such as the Dry Forests Symposium in 2011 to build the necessary momentum to put dry forests onto national and international agendas. By prioritizing research that fills knowledge gaps, CIFOR and its partners could strengthen and consolidate its existing work, broaden the available knowledge on dry forests in a relatively short time, and make substantial progress toward achieving its strategic goals, as well as contributing to global policy processes.

\section{Why focus on dry forests?}

Dry forests comprise slightly less than half of the world's subtropical and tropical forests (Murphy and Lugo 1986) and they support some of the world's poorest people (Campbell 1996; Cunningham et al. 2008; Waeber et al. 2012). For example, the African miombo alone is thought to provide livelihoods for more than 100 million people in urban and rural areas (Campbell et al. 2007; Syampungani et al. 2009; Dewees et al. 2011). Furthermore, dry forests provide a wide range of ecosystem services, thus playing an important and complex role in supporting the agricultural systems on which millions of subsistence farmers depend (Chidumayo and Gumbo 2010).

Despite their importance, dry forests are among the most threatened and least studied of the world's forested ecosystems and, as a result, may be at greater risk than humid forests (Janzen 1988; Miles et al. 2006; Portillo-Quintero and Sánchez-Azofeifa 2010; Aide et al. 2012; Gillespie et al. 2012). For example, the dry forests of some Pacific islands are thought to have been reduced to less than $10 \%$ of their original extent, with the remainder still threatened by human activity and the invasion of exotic species (Gillespie et al. 2012). It has also been suggested that the goods and services that dry forests provide are 
significantly different from those of humid forests, thus requiring different approaches to management and conservation (Wunder 2001; Makonda and Gillah 2007; Gumbo et al. 2010). Nevertheless, in both natural and social science, the focus of much forest-based discussion and research remains on humid forests (see, for example, Sánchez-Azofeifa et al. 2005; Malmer and Nyberg 2008).

Despite the clear and urgent need for site-specific, evidence-based policy to support dry forest management and conservation, much of the data and information required for such policy is absent or incomplete.

\section{Building on the past}

In recognizing the inherent value of dry forests, CIFOR has devoted considerable attention to supporting dry forest research. One of CIFOR's first occasional papers was dedicated to the miombo dry forests: Social and economical aspects of miombo woodland management in Southern Africa: Options and opportunities for research (Dewees 1994) was published just a year after the organization was founded. This was followed two years later by a complete book The Miombo in Transition: Woodlands and Welfare in Africa (Campbell 1996). In 2002, CIFOR developed a framework for dry forest research titled Africa's tropical dry forests - time to re-

\section{Box 1. Chronology of relevant strategic reviews}

1994 Social and economical aspects of miombo woodland management in Southern Africa: Options and opportunities for research. This paper noted that dry forests had been neglected in public discourse and that the emergence of community-based forest management institutions demanded greater attention on dry forests. Priority themes identified for research were: institutional change; household use of woodland products; markets for woodland products; long-term dimensions of exploitation; and policy and legislation. Author: Dewees P.

2002 Africa's tropical dry forests - time to re-engage: An agenda for priority research. The paper called for greater research along five themes: livelihoods; forest management; extra-sectoral trends; anticipating climate change; and north-south collaboration. Authors: Shepherd G, Chipeta M, Campbell B.

2005 Contributing to Africa's development through forests: Strategy for engagement in sub-Saharan Africa. This strategy was centered on the role of humid and dry forests in achieving the Millennium Development Goals, and was to focus on knowledge dissemination, capacity building, policy and equity. Author: CIFOR

2010 Opportunities for dry forest research within CIFOR. This report expanded the focus of dry forest research beyond Africa, identifying opportunities in a variety of areas including fuel, ecosystem services, carbon storage and agriculture. Authors: Gumbo E, Cunningham T, Shackleton C.

2011 New research agenda for Africa's dry forests defined at Durban. This article summarized the discussions at the Dry Forests Symposium held in 2011, during which the five priority themes for dry forest research used in this report were identified: climate change; food security and livelihoods; demand for energy; sustainable management; and policies and institutions to support sustainable management. Author: Sunderland T.

2012 In line with CIFOR's intention to expand research coverage of dry forests beyond Africa, two studies were commissioned to identify key research requirements in Latin America (Baldauf 2012) and South Asia (Waeber et al. 2012). The reports subsequently led to CIFOR convening a consultation with key dry forest stakeholders from those regions in Zurich, aimed at further developing a global research strategy and identifying important gaps in current research, i.e. this document.

2013 As a direct result of the Zurich workshop, a proposal for a journal special issue on dry forests was developed and accepted, pending review, by the International Forestry Review. It is anticipated this special issue will be published in early 2014 . 
engage: an agenda for priority research (Shepherd et al. 2002; see Box 1). In the decade since then, CIFOR has conducted research exclusively dedicated to dry forests, such as the Stimulating Policy Dialogue on Sustainable Management of Africa's Dry Forests program (Campbell et al. 2004) and the Dry Forests Project (Mwitwa and Bonkoungou 2009), as well as broader forest and livelihoods work with a significant dry forest component, such as the Landscape Management for Improved Livelihoods (LAMIL) project in Guinea (Sunderland-Groves et al. 2011).

To date, CIFOR's dry forest research has concentrated on Africa, partly because of the extent of dry forests on that continent and the large numbers of African people that rely on dry forests for their livelihoods and a range of goods and services. In 2010, CIFOR raised the profile of African dry forests through the publication of The Dry Forests and Woodlands of Africa: Managing for Products and Services (Chidumayo and Gumbo 2010). This book brought together a wide range of scientists conducting research on Africa’s dry forests to analyze management experiences and set out knowledge on sustainable use for the benefit of policy makers, practitioners and scientists.

CIFOR is now expanding its dry forest research to cover other regions of the world. The process began with a review titled Opportunities for dry forest research within CIFOR (Gumbo et al. 2010), aimed at raising the profile of dry forests within CIFOR and identifying potential research opportunities worldwide. Further development led to a symposium on dry forests in South Africa in 2011 (Dry Forests Symposium: A New Research Agenda for Africa, CIFOR 2011) and a review of the research opportunities in Latin American and South Asian dry forests in the following year (Baldauf 2012; Waeber et al. 2012). The symposium resulted in a new research agenda for dry forests that included the following themes:

- Climate change mitigation and adaptation;

- Food security and livelihoods;

- Demand for energy;

- Sustainable management of dry forests;

- Policies and institutions.

3 http://www.cifor.org/publications/pdf_files/Books/ BGumbo1001.pdf
This paper builds on previous work by outlining the state of worldwide dry forest knowledge for each of these themes.

\section{Global dry forests}

There is a notable lack of literature that examines dry forests from a global perspective, possibly due to the difficulties in defining what constitutes a dry forest, a topic that has been subject to extensive debate. However, some research on defining the extent of such forests is available (see FAO 2001; Miles et al. 2006; FAO 2012). The FAO has identified tropical dry forests as a Global Ecological Zone (GEZ), and defines tropical dry forests as those experiencing a "tropical climate, with summer rains ... a dry period of 5 to 8 months [and] annual rainfall ranges from 500 to $1500 \mathrm{~mm}$. [Dry forests include the] drier type of miombo and Sudanian woodlands, savannah (Africa), Caatinga and Chaco (South America) [and] dry deciduous Dipterocarp forest and woodlands (Asia)" (FAO 2001, 18). The FAO definition is used for the purposes of this review, and includes research conducted in areas with relatively open canopies such as woodlands, woody stands and other similar areas such as the Brazilian Cerrado. The FAO map of the tropical dry forest GEZ (reproduced in Appendix 3) shows that the largest areas of dry forest are in South America, sub-Saharan Africa and northeast India. Significant concentrations are also present throughout Southeast Asia, northern Australia and parts of the Pacific, Central America and the Caribbean.

According to Miles et al. (2006), less than one-third of the world's dry forest area lies within protected areas. Despite general agreement in the literature that dry forests are under threat (see Kowero 2003; Gillespie et al. 2012), comprehensive data on the rates of deforestation and conversion of dry forests are difficult to find. Portillo-Quintero and SánchezAzofeifa (2010) showed for the Americas that twothirds of tropical dry forest in the region has already been converted, with the rate as high as $95 \%$ in some countries. Aide et al. (2012) estimated that $200,000 \mathrm{~km}^{2}$ of dry forest and savannah lands in Latin America and the Caribbean were converted to other uses between 2001 and 2010. Data for other regions are much harder to come by. In general, deforestation/conversion data outside of 
Latin America are piecemeal, out of date (often from the 1980s), available at national/subnational level only or nonexistent. This is often because authoritative sources on deforestation and conversion trends, such as the FAO Global Assessment of Forest Resources (FAO 2010), do not differentiate between forest types. Scientific resources and capacity to conduct the relevant surveys are also an issue in many countries (Herold 2009). Furthermore, the drivers of deforestation across the regions are also poorly understood.

\section{Summary of research priorities}

Following are the main research priorities, in order of importance:

- Establish an agreed definition of tropical dry forests that CIFOR and related organizations can use to ensure consistency in how the term is used. The definition proposed by FAO (2001) would be suitable, given its simplicity and broad range.

- Establish national and global dry forest inventories, which appear to be lacking in most countries where such forests are found (Skutsch and $\mathrm{Ba} 2010$ ), partly due to capacity issues (Herold 2009; Herold and Johns 2007).

- Redress the regional and topical imbalances in existing knowledge, to improve coverage of biophysical aspects (especially deforestation), ecosystem services and sustainable intensification in Africa, Asia, the Caribbean and the Pacific. The majority of the literature covers the southern African miombo forests; this is particularly true for food security, livelihoods and community forestry. Latin America is increasingly receiving research attention, particularly related to carbon, payments for environmental services (PES), community forestry, novel conservation approaches (such as sustainable intensification for land sparing) and deforestation.

- Investigate human-forest interactions (beyond agriculture-forest frontier dynamics) in Latin America, Asia, the Caribbean and the Pacific. The role of dry forests in food security is of particular interest in this regard. In addition, Latin America and Africa can learn from each other's strengths in research methodologies. For example, methodologies applied to deforestation in Latin America might be very useful in informing similar studies in Africa. CIFOR is well placed to facilitate information sharing.

- Assess the impacts of cross-border and internal trade and investment, potential for carbon sequestration and environment-development trade-offs; these topics are under-researched in all regions and would benefit from evenly distributed research.

- Examine how the needs and demands of both humans and forestry systems change as societies change (for example, how the demands on forest management change with levels of poverty, equity, migration, urbanization, etc.). This is particularly relevant for dry forests, as many are located in regions where societies are undergoing rapid change, particularly through migration and rapidly growing populations.

\section{The regions at a glance: Where are the research gaps?}

\subsection{Latin America and Caribbean}

In 2012, CIFOR commissioned a report to identify research opportunities in the dry forests of Latin America (Baldauf 2012). The report's findings show the following:

Strengths:

- Latin American dry forests have possibly the strongest biophysical research base of all the regions, with a large number of studies documenting biophysical aspects (such as species population changes and carbon storage).

- Latin America has the most comprehensive deforestation data, with extensive use of remote sensing.

- The region is probably the best studied in terms of PES and carbon storage, with Mexico in particular the subject of much research.

- Livelihoods and community forestry have been extensively studied.

- Latin America is the best-represented area for research into agricultural intensification as a conservation tool through land sparing, although different studies have reached contrasting conclusions.

Gaps:

- The role of dry forests in the direct provision of food and in nutrition is not well documented, aside from a few studies with indigenous people. 
- Research in Latin America tends to concentrate on how humans affect the forest, resulting in a lack of information on how people use the forest apart from clearing it for agriculture (see Stoner and Sánchez-Azofeifa 2009).

- There is a need for greater research into forest users and uses, small-scale forest enterprises, climate change adaptation and the management of production forests.

- The Caatinga region of Brazil is one of the largest and most species-rich dry forest formations in Latin America but it is frequently classified as shrubland rather than as dry forest. As a result, the Caatinga may be excluded from relevant research and reporting (such as forest clearance figures); this issue (also present for some of the African miombo and Brazilian cerrado (Miles et al. 2006)) highlights the need for an accepted, standardized definition of dry forests.

- The Caribbean remains almost significantly unresearched with the exception of biophysical studies, most of which focus on the Caribbean mainland (for example, Gonzalez and Zak 1994; Bloem et al. 2006). Mapping and cataloguing the biophysical characteristics of these forests should be a high initial priority.

\subsection{Africa}

African dry forests, particularly the miombo and West African forest, have been extensively studied for decades. Nevertheless, some significant gaps remain.

Strengths:

- The region has by far the greatest body of research on livelihoods, food security, community management and conservation/development trade-offs.

- Small-scale enterprises and the impact of larger-scale trade and investment are also better researched in African dry forests than elsewhere.

- In East Africa, significant work has been conducted on some economically important dry forest products including honey and beeswax, and gums and resins from Acacia and Boswellia species.

- The body of research on carbon storage, the Reducing Emissions from Deforestation and Forest Degradation program (REDD) and ecosystem services is small but growing.

- Research on fuelwood and charcoal value chains is advanced, particularly in West Africa.

- The impacts of West African decentralization of forest management are well researched.
Gaps:

- Despite substantial research into biophysical aspects of African dry forests, reliable deforestation data are scarce (although deforestation data are available, most figures tend not to distinguish between forest types). This is particularly true in areas where such forests have not been officially classified as forests and are targeted for the development of commercial farming and resettlement schemes. Coverage could perhaps be improved by following the Latin American example of remote sensing, although there are technical and capacity obstacles to consider (see Herold 2009). The work of Mayaux et al. (2004) may provide a sound foundation for such work.

- The resilience of dry forest ecosystems, particularly in the face of deforestation, is poorly understood although such understanding is vital for effective management.

- Research into management of production forests is scarce.

- In East Africa research on the link between urbanization and dry forests in relation to wood energy and forest foods remains limited.

- CIFOR's research efforts into adaptation to climate change in African dry forests, although significant, have tended to be confined to West and Central African countries. The miombo woodlands of East and Southern Africa are poorly served by adaptation research; these might be a particular priority given the number of people reliant on these forests.

- The dry forests of Angola seem to be almost totally unresearched beyond a few biophysical studies, despite being found extensively throughout almost the entire country (Timberlake et al. 2010).

\subsection{Asia}

- Asian dry forests are not particularly well studied, despite being regionally extensive (Asian dry forests are defined here as encompassing the dry forests of Indochina as well as those of the Lesser Sundas and Central India). For example, Poffenberger (2000) found that up to $30 \%$ of forests in mainland Southeast Asia are classified as dry forest and Waeber et al. (2012) stated that up to $60 \%$ of Indian forests are comprised of dry forests. Although the FAO launched an Asian Dry Forests Initiative in the early 2000s, little activity has been evident over the past decade, and several important dry forest countries (such 
as Laos and Cambodia) are not participating (Appanah et al. 2003; FAO 2008).

- India has probably received the most research attention, with the following features:

- Some biophysical (see, for example,

Parthasarathy et al. 2008; Sagar et al. 2003), community forestry and livelihoods research is available.

- Livelihoods studies tend to have a narrow focus on non-timber forest products (NTFPs) and small enterprises, and little is known, for example, about the role of direct provisioning and subsistence usage (see Narendran et al. 2001; Mahapatra and Tewari 2005; Waeber et al. 2012).

- Research into community forestry, although well developed, tends to include other forest types, meaning that dry-forest-specific conclusions are not given.

- The dry forests of Thailand have been subject to some research, mostly on composition and human-induced changes (Bunyavejchewin 1983; Ghazoul 2002; Johnson 2002), as well as a narrow but very valuable collection of studies related to food use and the forest (see MorenoBlack and Price 1993; Moreno-Black et al. 1996; Price 1997; Somnasang and Moreno-Black 2000; Setalaphruk and Price 2007). Recent research on emerging themes such as climate change adaptation is lacking.

- Research specifically on dry forests in other parts of Asia is limited, although the region's dry forests do sometimes feature in studies that do not focus on a specific forest type.

\subsection{Pacific}

It appears that virtually nothing is known about the dry forests of the Pacific Islands, aside from one or two studies on their composition and conservation status and several archaeological studies on the history of the forest (see Blackmore and Vitousek 2000; Gillespie and Jaffré 2003; Pau et al. 2009; Gillespie et al. 2012). At the very least, the mapping and cataloguing of the biophysical characteristics of these forests should be a high priority. The International Union for the Conservation of Nature (IUCN) initiated a program focused on the dry forests of New Caledonia in the early 2000s, but little progress appears to have been made and the most recent activity dates back to 2002 (PFS 2004; IUCN 2012).

\section{The state of dry forest knowledge by theme}

\subsection{Theme 1: Climate change adaptation and mitigation}

Priority research areas

- Tools for estimating carbon stocks designed specifically for dry forests

- Scope and issues in developing carbon schemes in dry forests

- Role of dry forests in supporting human adaptation to climate change

Suggested geographic priorities

Latin America, Africa

\subsubsection{Estimating and managing carbon stocks in dry forests}

To date, research on carbon stocks has concentrated primarily on humid forests, for which the evidence base is well established. Estimating carbon stocks in dry forests requires a different approach, mainly because the above/below ground carbon ratio is different in dry forests.

The minimal attention paid to dry forests led Meister et al. (2012) to state, "almost nothing is known about [carbon flux and storage] in tropical dry forests". In terms of comprehensiveness, this may be the case, but researchers have developed and used tools and techniques at country or project level (see, for example, Eaton and Lawrence 2009; Návar 2009). Although the majority of this research activity has taken place in Latin America, examples are available for the dry forests of Asia and, to a lesser extent, Africa (Brown et al. 1993; Walker and Desanker 2004; Glenday 2008; Williams et al. 2008). On a wider scale, Saatchi et al. (2011) attempted to develop a cross-regional map showing forest carbon estimates for 75 countries, including all types of forest. However, many tools are of contested accuracy (see Cairns et al. 2003) and there is still considerable scope for further research into tools designed specifically for dry forests.

A priority for CIFOR, therefore, might be to identify research needs in order to build on existing tools and methods for estimating carbon stocks in dry forests. For example, a major issue with estimation 
tools is that they rely on forest inventories, which for many dry forests may be missing, incomplete or out of date (Skutsch and Ba 2010). Therefore, one of the most pressing requirements for supporting greater research under this theme is the development of reliable dry forest inventories. Another priority might be comparing and contrasting the drivers of deforestation between dry forest regions.

\subsubsection{The political economy of carbon trading schemes in dry forests}

Although it is often stated that carbon schemes such as REDD focus on humid forests because dry forests contain less carbon (Wertz-Kanounnikoff and Kongphan-apirak 2009), REDD schemes are planned for some dry forested regions and CIFOR has already begun research on such schemes in the miombo woodlands of Zambia and Mozambique (Wertz-Kanounnikoff et al. 2011). However, the understanding of how policies, governance and social structures will affect the success of such schemes is underdeveloped. For example, Baldauf (2012) suggested that in the Caatinga region of Brazil, socio-ecological conditions may require new models of payment schemes. Bond et al. (2010) sought to explore implications of existing policy and prospects for implementation of REDD in the miombo, but elsewhere policy analysis is severely lacking (see Miles 2010). Furthermore, where such analysis is available, conclusions are rarely separated by forest type (see, for example, Jindal et al. 2008; Byigero et al. 2010). This reveals an opportunity to undertake much greater research specifically on carbon trading and dry forests in all regions.

Of particular value might be intra-country comparison studies in states that are participating in REDD and have dry and humid forests in similar proportions (Cambodia or Madagascar, for example), to identify any inherent differences in how dry and humid forest schemes need to be administered.

Comparison studies investigating the relative merits and drawbacks of incentive schemes (such as community-based natural resource management [CBNRM], REDD and the Clean Development Mechanism) in the dry forest context would be especially valuable in informing the design of future interventions. The applicability of "lessons learned" from humid forest schemes in informing dry forest project design could also form the basis of focused research.

\subsubsection{Incorporating climate change adaptation into forest management}

For all regions, there is a striking lack of research on how climate change can be incorporated into dry forest management. Even the most common development issues that might affect how forests adapt to climate change, such as poverty or land tenure/control, remain poorly studied. Compounding this gap is a failure to consider forest adaptation in policy also. Although some innovative adaptation solutions have been identified in Brazil (Baldauf 2012), tropical dry forests frequently lack adaptation strategies, or else are subject to unworkable, unenforceable or poorly designed policies (see Dewees et al. 2011). For example, Lasco et al. (2008) found that in the Philippines, climate change has barely been considered within forest policy, even though dry forests are the most vulnerable forest system to climate change in the country. Although local people may apply indigenous technical knowledge to adaptation challenges, their efforts are rarely recognized or incorporated into formal approaches (Nyong et al. 2007).

Weaknesses in policy are partly attributable to a lack of empirical data, as there are only a few studies showing the likely impacts of climate change on dry forests (Miles et al. 2006). The forests of India appear to have received the most attention, with several studies considering the impact of climate change on different forest types in that country (Ravindranath and Sukumar 1998; Ravindranath et al. 2005; Sathaye et al. 2006). The number of studies is insufficient given the geographical extent of the world's dry forests, and available data have not yet been translated into the tools and guidance needed to support forest managers in incorporating adaptation into management.

Future research could build on Locatelli et al.'s (2008) "adaptation toolbox" by supporting research into narrower, localized solutions that can be transformed into practical tools and guidance for managers, particularly for smallholders that lack the resources for adaptation.

One approach could be to lead with a few pioneer countries, where the effects of climate change on dry forests would be studied in detail and tools could be developed and tested intensively. The first of these could be from Latin America, as dry forests on that continent are considered among the most at risk (Miles et al. 2006). 


\subsubsection{Improving the role of forestry in climate change adaptation}

Although the role of forestry in supporting adaptation is often acknowledged, it is rarely prioritized within adaptation strategies (Locatelli et al. 2008). For example, Mozambique, which contains large areas of tropical dry forest and woodlands, frequently refers to the importance of forest management for achieving priorities within its national action plan for adaptation to climate change (National Adaptation Programme of Action, or NAPA), but it does not consider forestry to be a priority in itself (Government of Mozambique 2007). Forestry has also been identified as one the four pillars in Ethiopia's climate resilient green economy strategy (Government of Ethiopia 2011), although the strategy does not distinguish different forest types, and the links have not been adequately articulated.

Integrating forests into adaptation strategies is considered important because forests are thought to have a far-reaching influence on adaptive capacity. However, the empirical evidence showing whether this applies to dry forests is not well developed. Evidence from Malawi suggests that forests can support rural households in adapting to climate change (Fisher et al. 2010), but studies of this type elsewhere are rare.

In some areas, other forest types are expected to transform into dry forests as the climate changes. The potential transformation of humid forest to other types, including dry forest, has been most widely documented in India (Ravindranath and Sukumar 1998; Ravindranath et al. 2005; Sathaye et al. 2006; Thompson et al. 2009). In these areas, new management and use strategies will be required, as dry forests provide different goods and services from those of other forest types.

Therefore, research should initially focus on how certain dry forests provide support/adaptation services to local populations, and how these services will be affected by climate change. This knowledge could then be used to demonstrate where dry forests are important to human adaptation, which will be useful in helping policy makers to better incorporate forests as a priority within adaptation strategies. Working with researchers on humid forests to determine where new dry forests are expected to emerge will also be valuable in assisting managers in those areas to manage the transition.
Work in this area could begin in African countries, because of the size and vulnerability of the populations that rely on the forests in that continent.

\subsection{Theme 2: Food security and livelihoods}

\section{Priority research areas}

- The scale of direct provisioning outside the miombo

- The importance of wild food to nutrition in all regions (quantitative, systematic reviews)

- The role of dry forests in livelihoods outside the miombo

- Ways that the poor can capture more of the added value of dry forest products

- The role of dry forests in ecosystem services in all regions

\subsubsection{Understanding the direct role of dry forests in food and nutrition}

Dry forests are thought to be extremely important in food security because of their direct role in providing food, particularly in times of scarcity and in extreme famine conditions. In addition, it is believed that the nutritional intake of people who live near dry forests is affected by the dietary and nutritional diversity of wild foods (see Ogle et al. 2001; Chidumayo and Marunda 2010; Shackleton et al. 2011).

The direct role of dry forests in food security in southern and West Africa has been extensively studied over many years, and information about direct provisioning from these forests is well developed. By contrast, outside Africa, there is almost no knowledge on the role of dry forests in the direct provisioning of food. Some studies on food from the forest have been undertaken in Latin America, but these are mostly ethnobotanical studies focusing almost exclusively on small groups of indigenous people, and research on wider rural populations is rare (for example, Arenas and Scarpa 2007; CamouGuerrero et al. 2008). This is unfortunate, because in some Latin American countries, dry forest areas are thought to be among the most food insecure (Baldauf 2012). What research is available suggests that Latin American forests are less important for food and used more for fuel and construction materials (Lucena et al. 2007), but this requires further research to confirm. Considerably more work is required for Asia (non-Indian) and the Pacific in particular. 
Although it is often stated that wild foods are essential in rural people's nutrition (see, for example, Bharucha and Pretty 2010; Shackleton and Gumbo 2010), the contribution of wild foods to nutrition is in fact under-researched and largely unknown. Few studies have recorded the nutritional value of various wild foods or the volumes of specific wild foods consumed by rural people. Research has been conducted in Thailand, Laos, South Africa, Burkina Faso, Mali, Brazil, Vietnam and Tanzania, but these tended to focus on a few aspects of a limited number and quantity of foods. Although the findings generally support the hypothesis that some wild foods can be nutritious, more research is required in all regions into the nutritional value of wild foods, diet deficiencies and actual consumption of specific wild foods.

The impact on food security of different management regimes, gender and poverty in dry forests are also important themes that remain under-researched in all regions.

\subsubsection{The role of dry forests to rural livelihoods}

Dry forests also contribute significantly to rural livelihoods. From beeswax to carbon, dry forests provide many products that can be sold. The African miombo alone is thought to contribute to the livelihoods of more than 100 million people in urban and rural areas (Campbell et al. 2007; Syampungani et al. 2009).

However, similar estimates are not available for other regions. As with direct provisioning, the African miombo has been the subject of the vast majority of research into livelihoods. Some studies have investigated livelihoods (particularly in relation to NTFPs) in Chile, Ethiopia, Mexico, Argentina, India and Thailand, but these remain quite isolated, and comprehensive data on livelihoods are not available. Much more research is required into the role of dry forests in the livelihoods of people in all areas outside the miombo, and expanding the existing body of knowledge should be a priority. Existing studies do suggest that dry forests contribute differently to the livelihoods of the poor and the non-poor (Jumbe et al. 2008; Abebaw et al. 2012) and that livelihood types differ between regions, but more research into this through comparison studies of different regions and socioeconomic research within regions would be useful. Research also indicates that the poor are rarely able to add value to the forest products that they sell, meaning that they capture only a negligible amount of the total product value. A further priority might be to investigate how to address this, for example by exploring integration in to existing value chains.

\subsubsection{The need to accurately assess environmental services}

Dry forests play a role in many of the environmental services that support food security indirectly. For example, dry forests may support livestock by providing a source of grazing, and the transfer of manure and leaf litter to fields is thought to be important in nutrient cycling and soil improvement (Scoones and Toulmin 1993; Campbell 1996; Clarke et al. 1996; Cavendish 2000; Marunda and Bouda 2010; Dewees et al. 2011). However, the role of forests in ecosystem services is complex and the methods for assessing forest contributions are still being refined.

CIFOR has prioritized the development of such methods within its general strategy and has published a variety of studies on ecosystem services, but without any specific dry forest component (see, for example, Meijaard et al. 2011). Methodologies to evaluate the contribution of dry forests to ecosystem services do exist, and this work is most advanced in Latin America, followed by the African miombo. Although the focus remains on carbon sequestration, the role of dry forests in water management, livestock provisioning, pollination services and nutrient cycling has been explored (Ricketts et al. 2004; Maass et al. 2005; Malmer and Nyberg 2008; Eaton and Lawrence 2009; Birch et al. 2010; del Castillo et al. 2011; Marunda and Bouda 2010; Carreño et al. 2012). However, the precise contribution that forests make to these services is not well understood and there is not yet an accepted methodology for assessing this contribution. Therefore, continued research is required in all regions, but particularly for the dry forests of Asia, notably Indochina, and the Pacific. Studies on ecosystem services assessment from peninsular Indian dry forests are in progress, but data useful to forest management and conservation will not be available for several years. The Pacific should be prioritized for this research, for several reasons: because the nature of small islands suggests that their forests would have a large influence on services; because little is known; and because sites could be defined relatively quickly and easily. 


\subsection{Theme 3: Demand for energy}

Priority research areas

- Basic supply and demand data for woodfuel and charcoal across the regions

- Alternative energy sources (e.g. rice husk briquettes)

- Policy options for energy demand management

Suggested geographic priorities

Asia, Latin America

The main role of dry forests in the demand for energy is the provision of fuel in the form of wood and charcoal. Although some dry forests may be affected by other energy-generating activities such as mining or hydroelectricity (for example, the Hwange dry forest region in Zimbabwe is also a center for coal extraction), there is little related research, probably because such cases are relatively isolated.

Research has mainly examined the impact of woodfuel and charcoal supply and demand on deforestation. Most of this research focused on the effect of fuel demand on deforestation in African dry forests and was conducted in the 1980s and 1990s (for example, Chidumayo 1987, 1991). There has also been limited research into the potential of woodfuel alternatives in Africa (see Foley and Buren 1982), and some research into sustainable management of forests for charcoal production (Chidumayo 1987; Gumbo et al. 2013). Since the early 1990s, interest in the subject appears to have declined but may now be increasing once more, with West Africa in particular being a focus for research (see Gautier et al. 2011; Teshome 2011). Arnold et al. (2003) argued that interest waned because woodfuel declined as a research priority internationally. Nevertheless, research does continue to some extent, often with a focus on charcoal or climate change (Kutsch et al. 2011; Luoga et al. 2000; Mwampamba 2007). Valuable research from West Africa has explored value chains for charcoal and woodfuel production, as well as the impact of decentralized and devolved forest management policies to manage production of fuel and other resources (Ribot 1998; Hautdidier and Gautier 2005; Gautier et al. 2011; Rives et al. 201).

The miombo continues to receive the greatest research interest. Although some research has been done in Latin America, including some useful efforts to build GIS supply and demand mapping tools for woodfuel (for example, Ghilardi et al. 2009), it often covers multiple forest types. Little of the work specific to dry forests takes fuel as the main topic, and rarely is it quantitative (see Turc and Mazzucco 1998; Castillo et al. 2005). However, it seems that in the Americas fuel is usually the most important resource derived from the forest, with heavy usage by the poor (de Albuquerque et al. 2005; Lucena et al. 2007; del Castillo et al. 2011; Suárez et al. 2012). Ramos et al. (2008) found that in the Caatinga region of Brazil local people identified 67 plants as combustible energy sources, only 37 of which were actually used. This suggests that there may be scope for research into the potential for greater exploitation of the remaining varieties.

Little work has been done on energy demand or supply in the dry forests of the Caribbean, and what is available either includes other forest types or focuses on demand from specific sectors only (for example, see Geist's (1999) review of the impact on Caribbean forests of the energy demands for tobacco curing).

Relatively little information is available from Asia, even though the region is thought to account for almost half of the world's woodfuel consumption (Arnold et al. 2003). A number of studies have been conducted in both India and Cambodia, but rarely have these focused on dry forests exclusively (Sagar and Singh 2004; Top et al. 2004a, 2004b, 2006).

Arnold et al. (2003) conducted a global review of tropical woodfuel research that includes dry forest and other forest types. Interestingly, the authors concluded that there is little evidence to show that demand for woodfuel has substantially outpaced supply (as was feared in the 1980s) and that fuel demands are rarely a cause of large-scale deforestation. By contrast, Makonda and Gillah (2007) argued that woodfuel demand is the second largest cause of deforestation in the developing world. Arnold et al. (2003) also argued that global demand for woodfuel is falling, demand for charcoal is rising and forestry strategies need to take into account changes in demand. Charcoal making is considered one of the most severe environmental threats to dry forests in southern Africa (Chidumayo and Kwibisa 2003), although there is some evidence that biodiversity can increase during the regeneration period following cutting, if the right management 
techniques are applied (Syampungani et al. 2009; Chidumayo and Gumbo 2012; Gumbo et al. 2013).

Finally, the demand for biofuel energy may have a large impact on dry forests. Although the focus overwhelmingly remains on humid forests, dry forests are beginning to receive attention as large-scale land acquisition (particularly in Africa) increases. There is a small but growing body of research on the topic, some of which has compared implications for dry forests across Latin America, Asia and Africa (German et al. 2011a; Baldauf 2012). Latin America and southern Africa are the best studied, with little research elsewhere.

The state of knowledge and changes in demand suggest that research priorities may need to change. Regardless of whether demand is falling, woodfuel remains extremely important in many developing countries, and biofuels are increasingly important in the EU and USA. Research needs to take into account changes in demand and consumption patterns of fuel types, including a potentially substantial international trade. There is also a need to build up some basic data for many areas of the world, particularly Latin America and Asia.

\subsection{Theme 4: Sustainable management of dry forests}

\section{Priority research areas}

- Dry-forest-specific silvicultural techniques for multiple outcomes (livelihoods, trade, conservation)

- Trade-offs in management regimes

- Common and important dry forest products outside the miombo

- Barriers to market penetration by new or underused products

\section{Suggested geographic priorities}

Asia, Latin America

\subsubsection{Improving management techniques for dry forests}

Systematic research into management practices for dry forests is important because of differences in the suitability of forestry techniques for humid and arid tropics (Long and Nair 1999). Biophysical and social systems also vary greatly across dry forest regions, as do the markets and local preferences that determine which forest products are valued. As such, sound understanding of management differences is necessary in setting research priorities and requirements.

Although there is a reasonably strong body of literature devoted to the technical aspects of managing forests for multiple outcomes (see Bellefontaine et al. 2000; Fox 2000; Hartley 2002; Fredericksen and Putz 2003; Evans et al. 2004; Brockerhoff et al. 2008), few of these studies focus specifically on dry forests (Baldauf 2012). Those that do tend to be focused on the African dry forests (for example, Chidumayo 1987, 1988; Dewees 1994; Lemenih et al. 2012), although there are a few guides from Asia and Latin America for specific products such as teak (Bucher and Huszar 1999; Krishnapillay 2000; Vieira and Scariot 2006; Villegas et al. 2009).

In West Africa, Rives et al. (2012) argue that an overreliance on technical aspects of forest management has prevented local forest users from defining their own techniques for sustainable management, and a growing body of literature supports the integration of indigenous and scientific management practices with the aim of improving biodiversity and other desirable outcomes, some of which focus on dry forest specifically (see Sabogal 1992; Michon et al. 2007; Nyong et al. 2007). Particularly lacking is information on Asian (non-Indian) and Pacific dry forest management.

Developing management practices depends on an understanding of the outputs and outcomes that are desirable and achievable for each forest. Research into the use of forest products is already part of CIFOR's strategy, but it would be valuable to extend this to examine dry forest areas in particular. There is a broad body of research on several dry forest products (honey, charcoal, baobab seeds, gums and resins), particularly in the African miombo, Ethiopia and the dry forests of West Africa (see, for example, Clarke et al. 1996; Campbell et al. 2004; Saka et al. 2007; Chidumayo and Gumbo 2010; Shackleton and Gumbo 2010; Lemenih and Kassa 2011). CIFOR has an opportunity to build on this, examining new ways in which these could be produced and be managed for multiple uses, as well as developing greater research into products from other areas. Information on dry forest products is limited in Asia, Latin America and the Pacific. 


\subsection{Theme 5: Policies and institutional support for sustainable management}

Priority research areas

- Analysis of existing forest policy from a dry forest perspective

- Impact and effectiveness of emerging policy/ institutional approaches to forest management (such as certification schemes or sustainable intensification)

- Impact of policies in other sectors on dry forests, including external economic forces

- Sustainability of trade at different scales

Suggested geographic priorities Africa, Asia

\subsubsection{Policies and regulation that influence forests}

Miles (2010) argued that, in general, there is not enough analysis of forest policy. In particular, research into contrasting tenure regimes within forestry is considered to be weak (Ravikumar et al. 2012), although some work has examined the effects of different forestry licensing regimes in the miombo (German et al. 2011a) and difficulties in regulating access rights in Ethiopia (Lemenih et al. 2012). Some academic analysis of policy has been done for most dry forest countries, but this tends not to analyze impacts on dry forests in particular, probably because few countries appear to have specific policies for dry forests. As many countries in sub-Saharan Africa have implemented new forestry policies within the past $10-15$ years (Wily 2001), there is a particular need for an analysis of the impacts of the legislation.

One area that has been well researched is the community and decentralized forest management policies that became popular in the 1980s and 1990s. This is most comprehensive for CBNRM in the miombo and West Africa and community forestry in Latin America, particularly Mexico (see Ribot 1998; Topp-Jørgensen et al. 2005; Raik and Decker 2007; Taber et al. 1997; Dalle et al. 2011; Baldauf 2012; Rives et al. 2012). Community forestry policy in India has also been well studied, but rarely with a focus on dry forests. These policies have led to new management institutions (discussed in Section 7.5.2). Research into the impact of certification schemes and other such approaches is also growing, but again without a focus on dry forests (Rametsteiner and
Simula 2003; van Dam 2003; Holvoet and Muys 2004; Espach 2006).

Forests may also be affected by institutions, policies and regulation in other sectors such as trade. Impacts of large-scale African economic development plans (such as "land grabbing") on forests have received some attention (see German et al. 2011b; Putzel and Kabuyaya 2011), as have global biofuels policies (see German et al. 2011a). Major trade-offs are clearly involved in implementing such policies (between conservation and development, or between local and national economic interests, for example); these are under-researched in dry forests (Schoneveld 2011). It is also necessary to consider the influence of non-forest institutions such as legal institutions, international donors, aid agencies and government departments, as the position of such institutions can, in some cases, heavily influence forest policies and use but, again, research specifically on dry forests is limited. Climate change and adaptation policies also affect forests, and are affected by them (see discussion in Section 7.1).

Clearly, much greater research into forest policy is needed. Analysis must examine the impact and effectiveness of current policies. For example, Dewees et al. (2011) argued that current policy in the Zambian miombo actually creates disincentives for sustainable management. Similar problems have been reported for policies and institutions in Latin America, which discourage the adoption of even relatively simple sustainability improvements (Baldauf 2012). More work of this type is required to understand how forest policy can be developed to take into account realities on the ground (for example, what can realistically be enforced? What is realistic to expect forests to deliver?). The policy implications for local people, conservation, development and adaptation to climate change are major areas for research. National forestry policy/ strategies may also need to be updated to take into account the multiple uses and functions of forests and the services they are now known to provide (such as food security, ecosystem services, livelihoods).

\subsubsection{Alternative institutions for conservation and management of dry forests}

Part of the reason why dry forests are among the most threatened of forest types (Miles et al. 2006) is that they are often found in areas of high population density, are rarely protected (Miles et al. 2006; Baldauf 2012) and are considered less attractive than 
other forest types in REDD/carbon payment schemes (Wertz-Kanounnikoff and Kongphan-apirak 2009; Baldauf 2012). Institutions tasked with protecting dry forests have a poor track record in many regions. As a result, a variety of alternative conservation approaches are emerging with the aim of improving conservation, often incorporating additional goals such as the reduction of poverty.

One topic that is receiving increasing attention is the potential for agricultural intensification to achieve conservation and development goals. Of all the regions with dry forests, Latin America is by far the best researched (see Grau et al. 2005, 2008; Grau and Aide 2008; Morton et al. 2008; Aide et al. 2012; Zimmerer 2013), although there is also some research from Malawi (Fisher and Shively 2006). The value of agricultural intensification for conservation remains contested (Angelsen and Kaimowitz 2001; GarcíaBarrios et al. 2009) and more research is needed in all regions.

Community forestry and other CBNRM in dry forests have been relatively well studied in most regions (see Taber et al. 1997; Bray et al. 2005; Poffenberger 2006; Sunderlin 2006; Ellis and Porter-Bolland 2008; Lund and Treue 2008; Kassa et al. 2009). In general, research into PES is most advanced in Latin America, as is community forestry and conservation through use (CTU) in dry forests (see, for example, Barrance et al. 2009); CBNRM has been most extensively studied in the miombo. Community forestry has been studied widely in India, but few studies cover dry forests exclusively. All regions lack systematic, dedicated research into alternative management systems in dry forests (as opposed to ad hoc research that happens to include dry forests). For example, although Indian community and joint forestry management systems have been well studied, most evaluations that include dry forests do so alongside a variety of forest types, making it difficult to distinguish dry forest peculiarities (see, for example, Conroy et al. 2002; Nayak and Berkes 2008).

Although dry forest systems are extremely diverse, there may be similarities in how they are used that can inform the development of institutions in different locations. For example, in most regions, there seems to be division of labor based on gender, which determines which type of wild forest resources are collected by men and women, and how they are used (Jain 1964; Cavendish 2000; Somnasang and Moreno-Black 2000; Camou-Guerrero et al. 2008; Jumbe et al. 2008; Shackleton et al. 2010; Asfaw et al. 2013). Understanding these divisions would be crucial in developing effective institutional arrangements, and recording similarities in divisions would be useful in identifying which regions might benefit from sharing information with each other.

A potential research focus could be based on exploring whether particular institutional arrangements are applicable to dry forests, and examining the constraints that are particularly pertinent to poor people in dry forests. For example, research from African dry forests shows that producer organizations often lack sufficient recognition to achieve their objectives effectively (Paumgarten et al. 2012), so research could investigate how to address this issue. Examining how institutions can be built such that they can respond flexibly to changes in economic and climatic conditions would be particularly valuable, given the location of dry forests and their vulnerability to climate change. Geographically, it would be valuable to spread research relatively evenly across the dry forest regions, but the Pacific stands out as the area about which the least is known.

\subsubsection{Support for small-scale business and trade}

Dry forests are the source of many of the goods used by small enterprises essential to the rural economy (Jumbe et al. 2008). Dry forest enterprises such as the collection of plants or insects may have low startup costs and are often accessible even to the very poor. For this reason, many institutions have an interest in supporting small enterprises as a means of economic development and poverty alleviation.

Yet developing policies and institutions to support small enterprises requires comprehensive knowledge of those enterprises. In Africa, in particular, dry forest enterprises such as honey, charcoal and insect sales are well documented, barriers to development have been identified and business guidelines developed (see, for example, Dewees et al. 2011; Paumgarten et al. 2012; Awono et al. 2013). In Asia and Latin America, similar research is available, but most studies tend to include a variety of forest types, hampering understanding of dry forest specifics. Baldauf (2012) also identified a number of issues with attempts to improve small-scale forest businesses in Latin America. Therefore, a priority in this theme would be to examine non-African dry forest areas 
more specifically. Prominent enterprises can then be the subject of further work on value chain analysis, sustainability, etc., to determine how they may be best supported. In particular, it should be a priority to investigate how to support poor producers/ collectors in adding value to their products through processing. It is well understood that the poorest are the most reliant on the forest, yet are rarely able to capture much of the total value of their products (Hegde and Bull 2008; Shackleton et al. 2010).

To support this research, more information is needed on users and uses of the forest, and how they will be affected by conservation or economic goals. This knowledge is underdeveloped in most regions outside the Africa miombo, but there seems to be differences in forest use between regions, for example, in gender roles (Somnasang and Moreno-Black 2000; Shackleton et al. 2010). This raises the concern that commercialization of forest products could actually harm the poor in some dry forest regions (Shackleton and Gumbo 2010), although not in others (MorenoBlack and Price 1993). There is also a need to examine how greater economic development will likely affect the forest. This research should be prioritized in Asia and the Pacific, where relatively little is known about how rural people use the forest.

\subsubsection{The impact of global trade and investment}

Although research into the impacts of trade and investment is well developed in most dry forest regions, few studies focus exclusively on dry forests. CIFOR has begun to address this by conducting several studies on dry forests, particularly in Africa and Latin America. Most prominent has been extensive work on the implications of biofuels, some of which compared implications for dry forests across Latin America, Asia and Africa (German et al. 2011a). The impact of Chinese investment on African dry forests is also becoming prominent (see German et al. 2011b; Putzel and Kabuyaya 2011).

CIFOR has also developed a framework approach that prioritizes six global regions for greater research (CIFOR 2012), including several important locations where dry forests are found in Asia, Africa, the Pacific and Latin America (although dry forests are not mentioned as a specific priority). The framework provides a useful opportunity to prioritize dry forests. CIFOR should build on its existing studies in dry forest regions to explore the impact of both internal and cross-border trade and investment on dry forests in Asia, the Pacific and the Caribbean.

\section{Conclusion}

Considerable research has been conducted into dry forests and their value to people across the world. CIFOR has made major contributions to this, primarily for Africa. Nevertheless, dry forests remain under-researched and under-prioritized in national and international policy. CIFOR has begun to expand its research on dry forests to cover those outside Africa (see, for example, Baldauf 2012; Waeber et al. 2012). The present review, which builds on CIFOR's earlier work, aims to support this goal.

Generally, the review reveals a clear need for an increase in the following:

- Up-to-date information on deforestation in African dry forests

- Livelihoods-based research in Latin America

- Research across the entire portfolio in Asia, the Pacific and the Caribbean.

For specific research topics, the assessment finds the following:

- Research on climate change and carbon is advanced for the dry forests of Latin America and parts of Africa, but severely lacking for other places.

- Food security and livelihoods have been well studied in parts of Africa, but in all other regions the role of dry forests in food security is under-researched, particularly the area of direct provisioning.

- Africa is well represented in research into energy supply and demand (particularly woodfuel and charcoal, but increasingly biofuels as well). Latin America has been the subject of extensive biofuels research.

- Novel management institutions such as community forestry have received the most attention in research on the dry forests of Latin America and Africa. India, although otherwise well studied on this topic, lacks research on dry forests.

- Greater research on sustainable management of dry forests specifically is required in all regions, as is analysis of forestry policy and policy in other sectors that affects dry forests.

CIFOR has used recent high-profile outputs such as the Dry Forests Symposium in 2011 to build the necessary momentum to put dry forests onto national and international agendas. By targeting research that fills knowledge gaps, CIFOR could strengthen and consolidate its existing work, broaden the available 
knowledge on dry forests in a relatively short time and make substantial progress toward achieving its strategic goals.

\section{References}

Abebaw D, Kassa H, Kassie GT, Lemenih M, Campbell B and Teka W. 2012. Dry forest based livelihoods in resettlement areas of Northwestern Ethiopia. Forest Policy and Economics 20:72-77.

Aide TM, Clark ML, Grau HR, López-Carr D, Levy MA, Redo D, Bonilla-Moheno M, Riner G, Andrade-Núñez M and Muñiz M. 2012. Deforestation and reforestation of Latin America and the Caribbean (2001-2010). Biotropica 45(2):262-71.

Angelsen A and Kaimowitz D. 2001. Introduction: The role of agricultural technologies in tropical deforestation. In Angelsen A and Kaimowitz D, eds. Agricultural Technologies and Tropical Deforestation New York: CABI/CIFOR. 1-18. http://www.cifor.org/publications/pdf_files/ Books/BAngelsen0101E0.pdf

Appanah S, Castaneda F and Durst PB, eds. 2003. Practical Guidelines for the Assessment, Monitoring and Reporting on National Level Criteria and Indicators for Sustainable Forest Management in Dry Forests in Asia Bangkok: Food and Agriculture Organization of the United Nations. ftp://ftp.fao.org/docrep/fao/006/ad640e/ ad640e00.pdf

Arenas P and Scarpa GF. 2007. Edible wild plants of the chorote Indians, Gran Chaco, Argentina. Botanical Journal of the Linnean Society 153(1):73-85.

Arnold M, Köhlin G, Persson R and Shepherd G. 2003. Fuelwood Revisited: What has changed in the last decade? CIFOR Occasional Paper No. 39. Bogor, Indonesia: Center for International Forestry Research. http://www.cifor.org/ publications/pdf_files/OccPapers/OP-39.pdf

Asfaw A, Lemenih M, Kassa $\mathrm{H}$ and Ewnetu Z. 2013. Importance, determinants and gender dimensions of forest income in eastern highlands of Ethiopia: The case of communities around Jelo Afromontane forest. Forest Policy and Economics 28(2013):1-7.

Awono A, Ingram V, Schure J and Levang P. 2013. Guide for Small and Medium Enterprises in the Sustainable Non-timber Forest Product Trade in Central Africa. Bogor, Indonesia: Center for International Forestry Research. http://
www.cifor.org/publications/pdf_files/Books/ BAwono1301.pdf

Baldauf C. 2012. Key research issues in global dry forests: Latin America. Unpublished report, Center for International Forestry Research, Bogor, Indonesia.

Barrance A, Schreckenberg K and Gordon J. 2009. Conservation Through Use: Lessons from the Mesoamerican Dry Forest. London: Overseas Development Institute. http://www.odi.org.uk/ sites/odi.org.uk/files/odi-assets/publicationsopinion-files/4426.pdf

Bellefontaine R, Gaston A and Petrucci Y. 2000. Management of Natural Forests of Dry Tropical Zones. FAO Conservation Guide No. 32. Rome: Food and Agriculture Organization of the United Nations. http://www.fao.org/docrep/005/ w4442e/w4442e00.HTM

Bharucha $\mathrm{Z}$ and Pretty J. 2010. The roles and values of wild foods in agricultural systems. Philosophical Transactions of the Royal Society of Biological Sciences 365:2913-26. http://rstb.royalsocietypublishing.org/ content/365/1554/2913.full.pdf + html

Birch JC, Newton AC, Aquino CA, Cantarello E, Echeverría C, Kitzberger T, Schiappacasse I and Garavito NT. 2010. Cost-effectiveness of dryland forest restoration evaluated by spatial analysis of ecosystem services. Proceedings of the National Academy of Sciences of the USA 107(50):21925-30. http://www.pnas.org/ content/107/50/21925.full.pdf + html

Blackmore M and Vitousek PM. 2000. Cattle grazing, forest loss, and fuel loading in a dry forest ecosystem at Pu'u Wa'aWa'a Ranch, Hawai' i. Biotropica 32(4a):625-32.

Bloem SJ, Lugo AE and Murphy PG. 2006. Structural response of Caribbean dry forests to hurricane winds: a case study from Guanica Forest, Puerto Rico. Journal of Biogeography 33(3):517-523.

Bond I, Chambwera M, Jones B, Chundama M and Nhantumbo I. 2010. REDD+ in Dryland Forests: Issues and Prospects for Pro-Poor REDD in the Miombo Woodlands of Southern Africa. Natural Resource Issues No. 21. London: International Institute for Environment and Development. http://pubs.iied.org/pdfs/17506IIED.pdf

Bray DB, Merino-Pérez L and Barry D. 2005. Community managed in the strong sense of the phrase: The community forest enterprises of Mexico. In Bray DB, Merino-Pérez L and Barry D, eds. The Community-Managed Forests of Mexico: The Struggle for Equity and Sustainability. 
Austin: University of Texas Press. 3-26. http:// www2.fiu.edu/ - brayd/CommunityForests.pdf

Brockerhoff EG, Jactel H, Parrotta JA, Quine CP and Sayer J. 2008. Plantation forests and biodiversity: Oxymoron or opportunity? Biodiversity and Conservation 17(5):925-51.

Brown S, Iverson LR, Prasad A and Liu D. 1993. Geographical distributions of carbon in biomass and soils of tropical Asian forests. Geocarto International 8(4):45-59.

Bucher EH and Huszar PC. 1999. Sustainable management of the Gran Chaco of South America: Ecological promise and economic constraints. Journal of Environmental Management 57(2):99-108.

Bunyavejchewin S. 1983. Analysis of the tropical dry deciduous forest of Thailand: I. Characteristics of the dominance-types. Natural History Bulletin of the Siam Society 31(2):109-22.

Byigero AD, Clancy J and Skutsch M. 2010. CDM in sub-Saharan Africa and the prospects of the Nairobi Framework Initiative. Climate Policy 10(2):181-89. http://doc.utwente.nl/70805/1/ climate_change_paper_-_alfred.pdf

Cairns MA, Olmsted I, Granados J and Argaez J. 2003. Composition and aboveground tree biomass of a dry semi-evergreen forest on Mexico's Yucatan Peninsula. Forest Ecology and Management 186(1):125-32.

Camou-Guerrero A, Reyes-García V, MartínezRamos M and Casas A. 2008. Knowledge and use value of plant species in a Rarámuri community: a gender perspective for conservation. Human Ecology 36(2):259-72.

Campbell B, ed. 1996. The Miombo in Transition: Woodlands and Welfare in Africa. Bogor, Indonesia: Center for International Forestry Research. http://www.cifor.org/publications/ pdf_files/books/miombo.pdf

Campbell BM, Angelsen A, Cunningham A, Katerere Y, Sitoe A and Wunder S. 2007. Miombo woodlands: Opportunities and barriers to sustainable forest management. Unpublished internal paper, Center for International Forestry Research. http://www.cifor.org/miombo/docs/ Campbell_BarriersandOpportunities.pdf

Campbell B, Frost P, Kokwe G, Le Breton G, Shackleton S and Tiveau D. 2004. Making dry forests work for the poor in Africa - building on success. CIFOR Forests Livelihoods Briefs No. 3. Bogor, Indonesia: Center for International Forestry Research. http://www.cifor.org/ntfpcd/ pdf/b5b.pdf
Carreño L, Frank FC and Viglizzo EF. 2012.

Tradeoffs between economic and ecosystem services in Argentina during 50 years of land-use change. Agriculture, Ecosystems and Environment 154:68-77.

Castillo A, Magaña A, Pujadas A, Martínez L and Godínez C. 2005. Understanding the interaction of rural people with ecosystems: A case study in a tropical dry forest of Mexico. Ecosystems 8(6):630-43.

Cavendish W. 2000. Empirical Regularities in the Poverty-Environment Relationship of Rural Households: Evidence from Zimbabwe. World Development 28(11):1979-2003.

[CIFOR] Center for International Forestry Research. 2005. Contributing to Africa's development through forests: Strategy for engagement in subSaharan Africa. Bogor, Indonesia: Center for International Forestry Research. http:// www.cifor.org/publications/pdf_files/Books/ PCIFOR0501.pdf

[CIFOR] Center for International Forestry Research. 2011. Dry Forests Conference: A New Research Agenda for Africa. Bogor, Indonesia: Center for International Forestry Research. http://blog.cifor. org/5614/new-research-agenda-for-africas-dryforests-defined-at-durban

[CIFOR] Center for International Forestry Research. 2012. Globalised Trade and Investment: Managing Impacts on Forests and People: A Framework Proposal. Bogor, Indonesia: Center for International Forestry Research. http://www. cifor.org/publications/pdf_files/frameworkproposal/D5-GlobalisationTrade.pdf

Chidumayo EN. 1987. A survey of wood stocks for charcoal production in the miombo woodlands of Zambia. Forest Ecology and Management 20:105-15.

Chidumayo EN. 1988. Estimating fuelwood production and yield in regrowth dry miombo woodland in Zambia. Forest Ecology and Management 24:59-66.

Chidumayo EN. 1991. Woody biomass structure and utilisation for charcoal production in a Zambian miombo woodland. Bioresource Technology $37: 43-52$.

Chidumayo E and Gumbo D. eds. 2010. The Dry Forests and Woodlands of Africa: Managing for Products and Services. London: Earthscan. http:// www.cifor.org/publications/pdf_files/Books/ BGumbo1001.pdf

Chidumayo EN and Gumbo D J. 2012. The environmental impacts of charcoal production 
in tropical ecosystems of the world: A synthesis. Energy for Sustainable Development 17(2):86-94.

Chidumayo E and Kwibisa L. 2003. Effects of deforestation on grass biomass and soil nutrient status in miombo woodland, Zambia. Agriculture, Ecosystems and Environment 96(1):97-105.

Chidumayo E and Marunda C. 2010. Dry forests and woodlands in sub-Saharan Africa: Context and challenges. In Chidumayo $\mathrm{E}$ and Gumbo D, eds. The Dry Forests and Woodlands of Africa: Managing for Products and Services. London: Earthscan. 1-10. http://www.cifor.org/ publications/pdf_files/Books/BGumbo1001.pdf

Clarke J, Cavendish W and Coote C. 1996. Rural households and miombo woodlands: Use, value and management. In Campbell $\mathrm{B}$, ed. The Miombo in Transition: Woodlands and Welfare in Africa. Bogor, Indonesia: Center for International Forestry Research. 101-36. http:// www.cifor.org/publications/pdf_files/books/ miombo.pdf

Conroy C, Mishra A and Rai A. 2002. Learning from self-initiated community forest management in Orissa, India. Forest Policy and Economics 4(3):227-37.

Cunningham A, German L, Paumgarten F, Chikakula M, Barr C, Obidzinski K, van Noordwijk M, de Koning R, Purnomo H, Yatich T, Svensson L, Gaafar A. and Puntodewo A. 2008. Sustainable trade and management of forest products and services in the COMESA region: an issue paper. Center for International Forestry Research, Bogor, Indonesia. http:// www.cifor.org/publications/pdf_files/Books/ BCunningham0801.pdf

Dalle SP, Pulido MT and Blois SD. 2011. Balancing shifting cultivation and forest conservation: Lessons from a "sustainable landscape" in southeastern Mexico. Ecological Applications 21(5):1557-72.

de Albuquerque UP, de Holande Cavalcanti Andrade $\mathrm{L}$ and de Silva ACO. 2005. Use of plant resources in a seasonal dry forest (Northeastern Brazil). Acta Botanica Brasilica 19(1):27-38.

del Castillo RF, Aguilar-Santelises R, Echeverría C, Ianni E, Mattenet M, Gómez G, Nahuelhal L, Malizia L, Ramirez-Marcial N, Schiappacasse I, et al. 2011. Socioeconomic valuation of dryland forest resources in dry areas of Argentina, Chile and Mexico. In Newton AC and Tejedor N, eds. Principles and Practice of Forest Landscape Restoration: Case Studies from the Drylands of
Latin America. Gland, Switzerland: International Union for Conservation of Nature. 183-204.

Dewees P. 1994. Social and economical aspects of miombo woodland management in Southern Africa: Options and opportunities for research. CIFOR Occasional Paper No. 2. Bogor, Indonesia: Center for International Forestry Research. http://www.cifor.org/publications/ pdf_files/OccPapers/OP-02n.pdf

Dewees P, Campbell B, Katerere Y, Sitoe A, Cunningham A, Angelsen AA and Wunder S. 2011. Managing the Miombo Woodlands of Southern Africa: Policies, Incentives, and Options for the Rural Poor. Washington, DC: Program on Forests (PROFOR). http://www.tandfonline. com/doi/pdf/10.1080/19390450903350846

do Nascimento VT, De Moura NP, da Silva Vasconcelos MA, Maciel MIS and de Albuquerque UP. 2011. Chemical characterization of native wild plants of dry seasonal forests of the semi-arid region of northeastern Brazil. Food Research International 44(7):2112-19.

Eaton JM and Lawrence D. 2009. Loss of carbon sequestration potential after several decades of shifting cultivation in the Southern Yucatán. Forest Ecology and Management 258(6):949-58.

Ellis EA and Porter-Bolland L. 2008. Is communitybased forest management more effective than protected areas? A comparison of land use/land cover change in two neighboring study areas of the Central Yucatan Peninsula, Mexico. Forest Ecology and Management 256(11):1971-83.

Espach R. 2006. When is sustainable forestry sustainable? The forest stewardship council in Argentina and Brazil. Global Environmental Politics 6(2):55-84. http://www.people.fas. harvard.edu/ $\sim$ hiscox/Espach.pdf

Evans J and Turnbull JW. 2004. Plantation Forestry in the Tropics: The Role, Silviculture, and Use of Planted Forests for Industrial, Social, Environmental, and Agroforestry Purposes. Oxford: Oxford University Press.

[FAO] Food and Agriculture Organization of the UN. 2001. FRA 2000: Global ecological zoning for the global forest resources assessment 2000: Final report. Rome: FAO. http://www.fao.org/ docrep/006/ad652e/ad652e00.HTM

[FAO] Food and Agriculture Organization of the UN. 2008. Regional initiative for the development and implementation of national level criteria and indicators for the sustainable management of $d r y$ forests in Asia. Accessed 29 May 2013. http:// www.fao.org/forestry/ci/16608@45613/en/ 
[FAO] Food and Agriculture Organization of the UN. 2010. Global Forest Resources Assessment 2010: Main Report. Rome: FAO. http://www. fao.org/docrep/013/i1757e/i1757e.pdf

[FAO] Food and Agriculture Organization of the UN. 2012. Global ecological zones for $F A O$ forest reporting: 2010 update. Forest Resources Assessment Working Paper 179. Rome: FAO. http://www.fao.org/docrep/017/ap861e/ ap861e00.pdf

Fisher M, Chaudhury M and McCusker B. 2010. Do forests help rural households adapt to climate variability? Evidence from Southern Malawi. World Development 38(9):1241-50.

Fisher M and Shively G. 2006. Agricultural subsidies and forest pressure in Malawis miombo woodlands. Paper Prepared for the 3rd World Congress of Environmental and Resource Economists Kyoto, Japan 3-7 July 2006.

Foley $\mathrm{G}$ and Buren A. 1982. Coal substitution and other approaches to easing the pressure on woodfuel resources. Natural Resources Forum 6(2):127-49.

Fox TR. 2000. Sustained productivity in intensively managed forest plantations. Forest Ecology and Management 138(1):187-202.

Fredericksen TS and Putz FE. 2003. Silvicultural intensification for tropical forest conservation. Biodiversity and Conservation 12(7):1445-53.

García-Barrios L, Galván-Miyoshi YM, ValdiviesoPérez IA, Masera OR, Bocco G and Vandermeer J. 2009. Neotropical forest conservation, agricultural intensification, and rural outmigration: The Mexican experience. Bioscience 59(10):863-73.

Gautier D, Hautdidier B, and Gazull L. 2011. Woodcutting and territorial claims in Mali. Geoforum, 42(1):28-39.

Geist HJ. 1999. Global assessment of deforestation related to tobacco farming. Tobacco Control 8:18-28. http://tobaccocontrol.bmj.com/ content/8/1/18.full

German L, Schoneveld GC and Pacheco P. 2011a. Local social and environmental impacts of biofuels: Global comparative assessment and implications for governance. Ecology and Society 16(4):29. http://www.ecologyandsociety.org/ vol16/iss $4 /$ art29/

German LA, Schoneveld GC, Wertz-Kanounnikoff $S$ and Gumbo D. 2011b. Chinese trade and investment and its impacts on forests: A scoping study in the miombo woodlands. CIFOR Working Paper No. 84. Bogor, Indonesia: Center for International Forestry Research. http://www.
cifor.org/publications/pdf_files/WPapers/ WP84German.pdf

Ghazoul J. 2002. Impact of logging on the richness and diversity of forest butterflies in a tropical dry forest in Thailand. Biodiversity and Conservation 11(3):521-41.

Ghilardi A, Guerrero G and Masera O. 2009. A GIS-based methodology for highlighting fuelwood supply/demand imbalances at the local level: A case study for Central Mexico. Biomass and Bioenergy 33(6):957-72.

Gillespie TW and Jaffré T. 2003. Tropical dry forests in New Caledonia. Biodiversity and Conservation 12(8):1687-97.

Gillespie T, Lipkin B, Sullivan L, Benowitz D, Pau $S$ and Keppel G. 2012. The rarest and least protected forests in biodiversity hotspots. Biodiversity and Conservation 21(14):3597-3611.

Glenday J. 2008. Carbon storage and emissions offset potential in an African dry forest, the ArabukoSokoke Forest, Kenya. Environmental Monitoring and Assessment 142(1-3):85-95.

Gonzalez OJ and Zak DR. 1994. Geostatistical analysis of soil properties in a secondary tropical dry forest, St. Lucia, West Indies. Plant and Soil 163(1):45-54.

Government of Ethiopia. 2011. Climate Resilient Green Economy Strategy. Ministry of Finance and Economic Development, Addis Ababa, Ethiopia. http://www.undp.org/content/dam/ethiopia/ docs/Ethiopia\%20CRGE.pdf

Government of Mozambique. 2007. National Adaptation Programme of Action. Maputo: Government of Mozambique. http://unfccc.int/ resource/docs/napa/moz01.pdf

Grau HR and Aide M. 2008. Globalization and landuse transitions in Latin America. Ecology and Society 13(2):16. http://www.ecologyandsociety. org/vol13/iss2/art16/

Grau HR, Gasparri NI and Aide TM. 2005. Agriculture expansion and deforestation in seasonally dry forests of north-west Argentina. Environmental Conservation 32(2):140-48.

Grau HR, Gasparri NI and Aide TM. 2008. Balancing food production and nature conservation in the neotropical dry forests of northern Argentina. Global Change Biology 14(5):985-97.

Gumbo D, Cunningham T and Shackleton C. 2010. Opportunities for dry forests research within CIFOR. Unpublished report, Center for International Forestry Research, Bogor, Indonesia. 
Gumbo D J, Moombe KB, Kandulu MM, Kabwe G, Ojanen M, Ndhlovu E and Sunderland TCH. 2013. Dynamics of the charcoal and indigenous timber trade in Zambia: A scoping study in Eastern, Northern and Northwestern provinces. Occasional Paper 86. CIFOR, Bogor, Indonesia. http://www.cifor.org/publications/pdf_files/ OccPapers/OP-86.pdf

Hartley MJ. 2002. Rationale and methods for conserving biodiversity in plantation forests. Forest Ecology and Management 155(1):81-95.

Hautdidier B and Gautier D. 2005. What local benefits does the implementation of rural wood markets in Mali generate? In Ros-Tonen MM and AJ Dietz, eds. African Forests between Nature and Livelihood Resource. New York: Edwin Mellen Press, pp. 191-220

Hegde R and Bull G. 2008. Economic Shocks and Miombo Woodland Resource Use: A Household Level Study in Mozambique. Vancouver: Department of Forest Resource Management, University of British Columbia. http://www.cifor.org/miombo/docs/ Mozambiquehouseholdlivelihoods_study.pdf

Herold M. 2009. An assessment of national forest monitoring capabilities in tropical non-Annex I countries: Recommendations for capacity building. Final report for the Prince's Rainforests Project and the Government of Norway. http:// princes.3cdn.net/8453c17981d0ae3cc8_ q0m6vsqxd.pdf

Herold $\mathrm{M}$ and Johns T. 2007. Linking requirements with capabilities for deforestation monitoring in the context of the UNFCCC-REDD process. Environmental Research Letters, 2(4).

Holvoet B and Muys B. 2004. Sustainable forest management worldwide: A comparative assessment of standards. International Forestry Review 6(2):99-122.

[IUCN] International Union for the Conservation of Nature. 2012. The Remarkable Biodiversity of Dry Forests. http://www.iucn.org/about/ union/secretariat/offices/europe/?10817/Theremarkable-biodiversity-of-dry-forests

Jain SK. 1964. Wild plant foods of the tribals of Bastar (Madhya Pradesh). Proceedings of the National Institute of Sciences of India 30(2):5680. http://www.dli.gov.in/data_copy/upload/ INSA/INSA_1/20005b76_56.pdf

Janzen D. 1988. Tropical dry forests, the most endangered major tropical ecosystem. In Wilson EO and Peter FM, eds. Biodiversity. Washington, DC: National Academy Press. 130-37.
Jindal R, Swallow B and Kerr J. 2008. Forestry-based carbon sequestration projects in Africa: Potential benefits and challenges. Natural Resources Forum 32(2):116-30.

Johnson N. 2002. Environmental change in Northern Thailand: Impact on wild edible plant availability. Ecology of Food and Nutrition 41(5):373-99.

Jumbe CB, Bwalya SM and Husselman M. 2008. Contribution of dry forests to rural livelihoods and the national economy in Zambia. Center for International Forestry Research, Bogor. http://www.cifor.org/miombo/docs/ ZambiaNationalCaseStudy.pdf

Kassa H, Campbell B, Sandewall M, Kebede M, Tesfaye Y, Dessie G, Seifu A, Tadesse M, Gardew $\mathrm{E}$ and Sandewall K. 2009. Building future scenarios and uncovering persisting challenges of participatory forest management in Chilimo forest, central Ethiopia. Journal of Environmental Management 90:1004-1013.

Kowero G. 2003. The challenge to natural forest management in sub-Saharan Africa rural development: Experiences from the miombo woodlands of Southern Africa. In Kowero G, Campbell B and Rashid Sumalia U, eds. Policies and Governance Structures in Woodlands of Southern Africa. Bogor, Indonesia: Center for International Forestry Research. 1-9. http:// www.cifor.org/publications/pdf_files/Books/ policies/Policies_SouthernAfrica-1.pdf

Krishnapillay B. 2000. Silviculture and management of teak plantations. Unasylva 51:14-21. http:// www.tropicalforest.ch/files/projects/PD_24_98_ article_2.pdf

Kutsch WL, Merbold L, Ziegler W, Mukelabai MM, Muchinda M, Kolle O and Scholes RJ. 2011. The charcoal trap: Miombo forests and the energy needs of people. Carbon Balance and Management 6(1):5. http://www.cbmjournal. com/content $/ 6 / 1 / 5$

Lasco RD, Pulhin FB, Sanchez P AJ, Villamor GB and Villegas KAL. 2008. Climate change and forest ecosystems in the Philippines: Vulnerability, adaptation and mitigation. Journal of Environmental Science and Management 11(1):1-14.

Lemenih M and Kassa H. 2011. Opportunities and Challenges for Sustainable Production and Marketing of Gums and Resins in Ethiopia. Bogor, Indonesia: CIFOR. http://www.cifor.org/ publications/pdf_files/Books/BKassa1102.pdf

Lemenih M, Kassa H, Kassie GT, Abebaw D and Teka, W. 2012. Resettlement and woodland 
management problems and options: A case study from north-western Ethiopia. Land Degradation and Development. DOI: 10.1002/ldr.2136

Locatelli B, Kanninen M, Brockhaus M, Colfer CJP, Murdiyarso Dand Santoso, H. 2008. Facing an uncertain future: How forests and people can adapt to climate change. Forest Perspectives No.

5. CIFOR, Bogor, Indonesia. http://www.cifor. org/publications/pdf_files/media/CIFOR_ adaptation.pdf

Long AJ and Nair PR. 1999. Trees outside forests: Agro-, community, and urban forestry. New Forests 17(1-3):145-74.

Lucena RF, Albuquerque UP, Monteiro JM, De Fatima Almeida C, Florentino AT and Ferraz JS. 2007. Useful plants of the semi-arid northeastern region of Brazil: A look at their conservation and sustainable use. Environmental Monitoring and Assessment 125(1-3):281-90.

Lund JF and Treue T. 2008. Are we getting there? Evidence of decentralized forest management from the Tanzanian miombo woodlands. World Development 36(12):2780-800.

Luoga EJ, Witkowski ETF and Balkwill K. 2000. Economics of charcoal production in miombo woodlands of eastern Tanzania: Some hidden costs associated with commercialization of the resources. Ecological Economics 35(2):243-57.

Maass JM, Balvanera P, Castillo A, Daily GC, Mooney HA, Ehrlich P, Quesada M, Miranda A, Jaramillo V, García-Oliva F, et al. 2005. Ecosystem services of tropical dry forests: Insights from long-term ecological and social research on the Pacific Coast of Mexico. Ecology and Society 10(1):17. http://www. ecologyandsociety.org/vol10/iss1/art17/

Mahapatra A and Tewari D. 2005. Importance of non-timber forest products in the economic valuation of dry deciduous forests of India. Forest Policy and Economics 7(3):455-67.

Makonda F and Gillah P. 2007. Balancing wood and non-wood products in miombo woodlands. Working Papers of the Finnish Forest Research Institute 50:64-70. http://www.metla.fi/ julkaisut/workingpapers/2007/mwp050-07.pdf

Malmer A and Nyberg G. 2008. Forest and water relations in miombo woodlands: Need for understanding of complex stand management. Working Papers of the Finnish Forest Research Institute 98:70-86. http://www.metla.fi/ julkaisut/workingpapers/2008/mwp098-10.pdf

Marunda C and Bouda H. 2010. Environmental services from the dry forests and woodlands of sub-Saharan Africa. In Chidumayo $\mathrm{E}$ and
Gumbo D, eds. The Dry Forests and Woodlands of Africa: Managing for Products and Services London: Earthscan. 231-60. http://www. cifor.org/publications/pdf_files/Books/ BGumbo1001.pdf

Mayaux P, Bartholome E, Fritz $S$ and Belward A. 2004. A new land-cover map of Africa for the year 2000. Journal of Biogeography 31(6):861-877.

Meijaard E,Sheil D, Guariguata MNasi R, Sunderland T and Putzel L. 2011 Ecosystem services certification: opportunities and constraints. Occasional Paper 66. CIFOR, Bogor, Indonesia. http://www.cifor.org/online-library/browse/viewpublication/publication/3500.html

Meister K, Ashton MS, Craven D and Griscom H. 2012. Carbon dynamics of tropical forests. In Ashton M, Spalding TD and Gentry B, eds. Managing Forest Carbon in a Changing Climate. Berlin: Springer. 51-75.

Michon G, De Foresta H, Levang P and Verdeaux F. 2007. Domestic forests: A new paradigm for integrating local communities' forestry into tropical forest science. Ecology and Society 12(2):1. http://www.ecologyandsociety.org/ vol12/iss $2 /$ art $1 /$

Miles L. 2010. Implications of the REDD Negotiations for Forest Restoration. Cambridge, UK: UNEP World Conservation Monitoring Centre. http:// www.undpcc.org/undpcc/files/docs/publications/ submited/Restoration\%20REDD\%20 briefing\%20lo-res.pdf

Miles L, Newton A, DeFries R, Ravilious C, May I, Blyth S, Kapos V and Gordon J. 2006. A global overview of the conservation status of tropical dry forests. Journal of Biogeography 33(3):491-505.

Moreno-Black G, Akanan W, Somnasang P, Thamathawan S and Brozvosky P. 1996. Nondomesticated food resources in the marketplace and marketing system of Northeastern Thailand. Journal of Ethnobiology 16:99-118.

Moreno-Black G and Price LL. 1993. The marketing of gathered food as an economic strategy of women in Northeastern Thailand. Human Organization 52(4):398-404.

Morton DC, Defries RS, Randerson JT, Giglio L, Schroeder W and van der Werf GR. 2008. Agricultural intensification increases deforestation fire activity in Amazonia. Global Change Biology 14(10):2262-75.

Murphy P and Lugo A. 1986. Ecology of tropical dry forest. Annual Review of Ecology and Systematics 17:67-88. 
Mwampamba TH. 2007. Has the woodfuel crisis returned? Urban charcoal consumption in Tanzania and its implications to present and future forest availability. Energy Policy 35(8):4221-34.

Mwitwa J and Bonkoungou E. 2009. External evaluation report of CIFOR's dry forest research in sub-Saharan Africa. Unpublished report, Center for International Forestry Research.

Narendran K, Murthy I, Suresh H, Dattaraja H, Ravindranath N and Sukumar R. 2001. Nontimber forest product extraction, utilization and valuation: A case study from the Nilgiri Biosphere Reserve, southern India. Economic Botany 55(4):528-38.

Návar J. 2009. Allometric equations for tree species and carbon stocks for forests of northwestern Mexico. Forest Ecology and Management 257(2):427-34.

Nayak PK and Berkes F. 2008. Politics of cooptation: Community forest management versus joint forest management in Orissa, India. Environmental Management 41(5):707-18.

Nyong A, Adesina F and Elasha BO. 2007. The value of indigenous knowledge in climate change mitigation and adaptation strategies in the African Sahel. Mitigation and Adaptation Strategies for Global Change 12(5):787-97.

Ogle B, Huang Hung P and Thi Tuyet H. 2001. Significance of wild vegetables in micronutrient intakes of women in Vietnam: An analysis of food variety. Asia Pacific Journal of Clinical Nutrition 10(1):21-30.

Parthasarathy N, Selwyn MA and Udayakumar M. 2008. Tropical dry evergreen forests of peninsular India: Ecology and conservation significance. Tropical Conservation Science 1:89-110. http://tropicalconservationscience. mongabay.com/content/v1/08-06-09Parthasarathy_et_al.html

Pau S, Gillespie TW and Price JP. 2009. Natural history, biogeography, and endangerment of Hawaiian dry forest trees. Biodiversity and Conservation 18(12):3167-82.

Paumgarten F, Kassa H, Zida M and Moeliono M. 2012. Benefits, challenges, and enabling conditions of collective action to promote sustainable production and marketing of products from Africa's dry forests. Review of Policy Research 29(2):229-50.

Poffenberger M, ed. 2000. Communities and Forest Management in Southeast Asia. Gland, Switzerland: International Union for the
Conservation of Nature. http://www. asiaforestnetwork.org/pub/pub29.pdf

Poffenberger M. 2006. People in the forest: Community forestry experiences from Southeast Asia. International Journal of Environment and Sustainable Development 5(1):57-69.

Portillo-Quintero, C. and Sánchez-Azofeifa, G. 2010. Extent and conservation of tropical dry forests in the Americas. Biological Conservation 143(1):144-155.

Price LL. 1997. Wild plant food in agricultural environments: A study of occurrence, management, and gathering rights in Northeast Thailand. Human Organization 56(2):209-21.

[PFS] Programme Foret Seche. 2004. Research and Studies. http://www.foretseche.nc/EN_index.htm

Putzel L and Kabuyaya N. 2011. Chinese aid, trade and investment and the forests of the Democratic Republic of Congo. CIFOR Working Paper No. 82. Bogor, Indonesia: Center for International Forestry Research. http://www.cifor.org/ publications/pdf_files/WPapers/WP67Putzel.pdf

Raik DB and Decker DJ. 2007. A multisector framework for assessing community-based forest management: Lessons from Madagascar. Ecology and Society 12(1):14. http://www. ecologyandsociety.org/vol12/iss1/art14/

Rametsteiner E and Simula M. 2003. Forest certification: An instrument to promote sustainable forest management? Journal of Environmental Management 67(1):87-98.

Ramos MA, Muniz de Medeiros P, Santos de Almeida AL, Feliciano ALP and de Albuquerque UP. 2008. Use and knowledge of fuelwood in an area of caatinga vegetation in NE Brazil. Biomass and Bioenergy 32(6):510-17.

Ravikumar A, Andersson K, Mwangi E, Guariguata MR and Nasi R. 2012. Towards more equitable terms of cooperation: Local people's contribution to commercial timber concessions. International Forestry Review 14(2):157-76.

Ravindranath NH, Joshi NV, Sukumar R and Saxena A. 2005. Impact of climate change on forests in India. Unpublished paper, Cornell University. http://arxiv.org/abs/q-bio/0511001

Ravindranath NH and Sukumar R. 1998. Climate change and tropical forests in India. Climatic Change 39(2-3):563-81.

Redo D, Aide TM and Clark ML. 2012. Vegetation change in Brazil's dryland ecoregions and the relationship to crop production and environmental factors: Cerrado, Caatinga, and Mato Grosso, 2001-2009. Journal of Land Use Science. 8(2):1-31. 
Ribot JC. 1998. Theorizing access: Forest profits along Senegal's charcoal commodity chain. Development and Change, 29(2):307-341.

Ricketts TH, Daily GC, Ehrlich PR and Michener CD. 2004. Economic value of tropical forest to coffee production. Proceedings of the National Academy of Sciences of the USA 101(34):12579-82. http://www.pnas.org/ content/101/34/12579.full.pdf

Rives F, Peltier Rand Montagne P. 2012. Fifteen years of forest community management in Niger: from a technician's dream to social reality. Small-Scale Forestry 12:87-105.

Saatchi SS, Harris NL, Brown S, Lefsky M, Mitchard ET, Salas W, Zutta B, Buermann W, Lewis S, Hagen S, et al. 2011. Benchmark map of forest carbon stocks in tropical regions across three continents. Proceedings of the National Academy of Sciences of the USA 108(24):9899-904. http://www.pnas.org/content/108/24/9899.full. pdf + html

Sabogal C. 1992. Regeneration of tropical dry forests in Central America, with examples from Nicaragua. Journal of Vegetation Science 3(3):407-16.

Sagar R, Raghubanshi AS and Singh JS. 2003. Tree species composition, dispersion and diversity along a disturbance gradient in a dry tropical forest region of India. Forest Ecology and Management 186(1):61-71.

Sagar R and Singh JS. 2004. Local plant species depletion in a tropical dry deciduous forest of northern India. Environmental Conservation 31(1):55-62.

Saka JDK, Kadzere I, Ndabikunze BK, Akinnifesi FK and Tiisekwa BPM. 2007. Product development: nutritional value, processing and utilization of indigenous fruits from the miombo ecosystem. In Leakey $\mathrm{R}$ and Ajayi O, eds. Indigenous Fruit Trees in the Tropics: Domestication, Utilization and Commercialization. Oxford, UK: CABI.

Sánchez-Azofeifa GA, Quesada M, Rodríguez JP, Nassar JM, Stoner KE, Castillo A, Garvin T, Zent E, Calvo-Alvarado J, Kalacska M, et al. 2005. Research priorities for neotropical dry forests. Biotropica 37(4):477-85.

Sathaye J, Shukla PR and Ravindranath NH. 2006. Climate change, sustainable development and India: Global and national concerns. Current Science Bangalore 90(3):314.

Schoneveld GC. 2011. The anatomy of large-scale farmland acquisitions in sub-Saharan Africa. CIFOR Working Paper No. 85. Bogor, Indonesia: Center for International Forestry
Research. http://www.cifor.org/publications/ pdf_files/WPapers/WP85Schoneveld.pdf

Scoones I and Toulmin C. 1993. Socio-economic dimensions of nutrient cycling in agropastoral systems of dryland Africa. In Powell J, Fernandez-Rivera S, Williams T and Renard C, eds. Livestock and Sustainable Nutrient Cycling in Mixed farming Systems of sub-Saharan Africa: Volume 2, Technical Papers. Addis Ababa. ILCA

Setalaphruk C and Price L. 2007. Children's traditional ecological knowledge of wild food resources: A case study in a rural village in northeast Thailand. Journal of Ethnobiology and Ethnomedicine 3:33.

Shackleton S, Cocks M, Dold T, Kaschula S, Mbata K, Mickels-Kokwe G and von Maltitz G. 2010. Non-wood forest products: Description, use and management. In Chidumayo $\mathrm{E}$ and Gumbo D, eds. The Dry Forests and Woodlands of Africa: Managing for Products and Services. London: Earthscan. 93-130. http://www.cifor.org/ publications/pdf_files/Books/BGumbo1001.pdf

Shackleton S, Delang CO and Angelsen A. 2011. From subsistence to safety nets and cash income: Exploring the diverse values of non-timber forest products for livelihoods and poverty alleviation. Tropical Forestry No. 7. In Shackleton S, Delang $\mathrm{CO}$ and Shanley P, eds. Non-Timber Forest Products in the Global Context. Heidelberg: Springer-Verlag. 55-81.

Shackleton S and Gumbo D. 2010. Contribution of non-wood forest products to livelihoods and poverty alleviation. In Chidumayo $\mathrm{E}$ and Gumbo D, eds. The Dry Forests and Woodlands of Africa: Managing for Products and Services London: Earthscan. http://www.cifor.org/ publications/pdf_files/Books/BGumbo1001.pdf

Shepherd G, Chipeta M and Campbell B. 2002. Africa's tropical dry forests - time to re-engage: An agenda for priority research. Bogor, Indonesia: Center for International Forestry Research. 63-92. http://www.cifor.org/publications/pdf_ files/Books/Dryforestreport.pdf

Skutsch MM and Ba L. 2010. Crediting carbon in dry forests: The potential for community forest management in West Africa. Forest Policy and Economics 12(4):264-70.

Somnasang P and Moreno-Black G. 2000. Knowing, gathering and eating: Knowledge and attitudes about wild food in an Isan village in Northeastern Thailand. Journal of Ethnobiology 20(2):197-216.

Stoner KE and Sánchez-Azofeifa GA. 2009. Ecology and regeneration of tropical dry forests in the 
Americas: Implications for management. Forest Ecology and Management 258(6):903-906.

Suárez A, Williams-Linera G, Trejo C, ValdezHernández JI, Cetina-Alcalá VM and Vibrans H. 2012. Local knowledge helps select species for forest restoration in a tropical dry forest of central Veracruz, Mexico. Agroforestry Systems 85(1):35-55.

Sunderland T. 2011. New Research agenda for africa's dry forests defined at Durban. http://blog.cifor. org/5614/

Sunderland-Groves J, Slayback D, Balinga M and Sunderland T. 2011. Impacts of co-management on western chimpanzee (Pan troglodytes verus) habitat and conservation in Nialama Classified Forest, Republic of Guinea: a satellite perspective. Biodiversity and Conservation 20(12):2745-2757.

Sunderlin WD. 2006. Poverty alleviation through community forestry in Cambodia, Laos, and Vietnam: An assessment of the potential. Forest Policy and Economics 8(4):386-96.

Syampungani S, Chirwa PW, Akinnifesi FK, Sileshi G and Ajayi OC. 2009. The miombo woodlands at the cross roads: Potential threats, sustainable livelihoods, policy gaps and challenges. Natural Resources Forum 33(2):150-59.

Taber A, Navarro G and Arribas MA. 1997. A new park in the Bolivian Gran Chaco: An advance in tropical dry forest conservation and communitybased management. Oryx 31(3):189-98.

Teshome B. 2011. Determinants of engagement in and dependence on forest products: The case of gums and resins in the dry forest areas of Tigray, Amhara and Oromiyia National regional States of Ethiopia. MSc Thesis. Hawassa University, Wondo Genet College of Forestry and Natural resources, Wondo Genet, Ethiopia.

Thompson I, Mackey B, McNulty S and Mosseler A. 2009. Forest resilience, biodiversity, and climate change: A synthesis of the biodiversity/resiliencel stability relationship in forest ecosystems. Technical Series No. 43. Montreal: Secretariat of the Convention on Biological Diversity. http://www. cbd.int/doc/publications/cbd-ts-43-en.pdf

Timberlake J, Chidumayo E and Sawadogo L. 2010. Distribution and characteristics of African dry forests and woodlands. In Chidumayo $\mathrm{E}$ and Gumbo D, eds. The Dry Forests and Woodlands of Africa: Managing for Products and Services. London: Earthscan. 11-42. http:// www.cifor.org/publications/pdf_files/Books/ BGumbo1001.pdf
Top N, Mizoue N, Ito S, Kai S, Nakao T and Ty S. 2006. Re-assessment of woodfuel supply and demand relationships in Kampong Thom Province, Cambodia. Biomass and Bioenergy 30(2):134-43.

Top N, Mizoue N, Ito S and Kai S. 2004b. Spatial analysis of woodfuel supply and demand in Kampong Thom Province, Cambodia. Forest Ecology and Management 194(1): 369-78.

Top N, Mizoue N and Kai S. 2004a. Estimating forest biomass increment based on permanent sample plots in relation to woodfuel consumption: A case study in Kampong Thom Province, Cambodia. Journal of Forest Research 9(2):117-23.

Topp-Jørgensen E, Poulsen MK, Lund JF and Massao JF. 2005. Community-based monitoring of natural resource use and forest quality in montane forests and miombo woodlands of Tanzania. Biodiversity and Conservation 14(11):2653-77.

Turc CO and Mazzucco RV. 1998. Harvesting systems used in the Dry Chaco forests of Argentina. Quebracho 6:59-68.

Van Dam C. 2003. The economics of forest certification sustainable development for whom? Presentation, Latin American Congress on Development and Environment: Local Challenges of Globalisation. FLACSO, Quito, Ecuador, 11-12 April.

Vieira DL and Scariot A. 2006. Principles of natural regeneration of tropical dry forests for restoration. Restoration Ecology 14(1):11-20.

Villegas Z, Peña-Claros M, Mostacedo B, Alarcón A, Licona JC, Leaño C, Pariona W and Choque U. 2009. Silvicultural treatments enhance growth rates of future crop trees in a tropical dry forest. Forest Ecology and Management 258(6):971-77.

Waeber P, Ramesh B, Parthasarathy N, Pulla S and Garcia C. 2012. Seasonally dry tropical forests in South Asia: A research agenda. A research agenda to contribute to the discussions on "Key Issues for the Global Dry Forests" workshop organized by CIFOR/ForDev in Zurich, 28-30th October 2012.

Walker SM and Desanker PV. 2004. The impact of land use on soil carbon in miombo woodlands of Malawi. Forest Ecology and Management 203(1):345-60.

Wertz-Kanounnikoff $S$ and Kongphan-apirak M. 2009. Emerging REDD+: A preliminary survey of demonstration and readiness activities. CIFOR Working Paper No. 46. Bogor, Indonesia: Center for International Forestry Research. http:// 
www.forestforclimate.org/attachments/548_ WP46Wertz-Kanounnikoff.pdf

Wertz-Kanounnikoff S, Sitoe A and Salomão A.

2011. How is REDD+ unfolding in Southern Africa's Dry Forests? A snapshot from Mozambique. CIFOR Info Brief No. 37. Bogor, Indonesia: Center for International Forestry Research. http://www.cifor.org/publications/pdf_files/ infobrief/3402-infobrief.pdf

Williams M, Ryan CM, Rees RM, Sambane E, Fernando J and Grace J. 2008. Carbon sequestration and biodiversity of r-growing miombo woodlands in Mozambique. Forest Ecology and Management 254(2):145-55.
Wily LA. 2001. Forest Management and Democracy in East and Southern Africa: Lessons from Tanzania. IIED Gatekeeper Series No. 95 London: International Institute for Environment and Development. http://pubs.iied.org/ pdfs/6350IIED.pdf

Wunder S. 2001. Poverty alleviation and tropical forests: What scope for synergies? World Development 29(11):1817-33.

Zimmerer KS. 2013. The compatibility of agricultural intensification in a global hotspot of smallholder agrobiodiversity (Bolivia).

Proceedings of the National Academy of Sciences of the USA 110(8): 2769-74. http://www.pnas. org/content/early/2013/01/29/1216294110.full. pdf + html 


\section{Annex 1: Potential research questions by theme ${ }^{4}$}

\section{Theme 1: Climate change adaptation and mitigation}

\subsection{Estimating and managing carbon stocks in dry forests}

- How do carbon stock management techniques differ between humid and dry forests, and what does this mean for climate mitigation models?

- What are the advantages and disadvantages of available carbon estimation tools, and how could research assist in improving these tools?

- What degree of accuracy is required in the estimation of dry forest carbon, and what are the consequences of inaccuracy?

- How can the carbon stock of dry forests be estimated accurately, given that much of the stock is held below ground?

- Assuming accurate estimates can be delivered, what are the other key issues in carbon management in dry forest institutions (e.g., capacity, funding, public perception)?

\subsection{The political economy of carbon trading schemes in dry forests}

- Are the assumptions behind REDD and other relevant schemes supported by evidence in dry forests?

- What are the key factors in the success/failure of historical policies and mechanisms that could inform the design of carbon payment schemes for dry forests?

- What other carbon market opportunities exist for dry forest countries?

- What are the implications for other areas (livelihoods, food production, economic growth, land tenure) if dry forest carbon schemes are more widely implemented?

- How do carbon sequestration schemes compare to other livelihoods options in dry forests? What are the opportunity costs?

- Are there factors specific to dry forests that influence the adoption and effectiveness of potential carbon schemes?

- How do the barriers to adoption of schemes differ between dry forest regions?
- Are countries with experience in humid forest $\mathrm{REDD} /$ carbon schemes better placed to implement successful dry forest schemes? What lessons can be learned from countries that have both humid and dry forest schemes?

\subsection{Incorporating climate change adaptation into forest management}

- What are the likely impacts of climate change on specific dry forests?

- What factors constrain and enable managers in incorporating adaptation into management?

- What tools can managers use to incorporate climate change adaptation into management?

- How can local technical knowledge of climate change adaptation be integrated into formal adaptation strategies?

- How else can managers be supported to mitigate or adapt to forest changes?

- It is suggested that the initial focus be on dry forests in Latin America because of their vulnerability to climate change (Miles et al. 2006).

\subsection{Improving the role of forestry in climate change adaptation}

- What are the likely impacts of climate change on specific dry forests in terms of their ability to continue to provide support services to their populations?

- How can dry forests help their populations cope with climate change (e.g. by providing new goods and services)?

- Where will new dry forests emerge and how can managers in these areas be supported to manage the changes?

- How will changes in forest type affect the populations that rely on the forests?

- How can forestry be better incorporated as a priority within adaptation strategies?

- It is suggested that the initial focus be on dry forests in African countries because of the size and vulnerability of the populations that rely on them. 


\section{Theme 2: Food security and livelihoods}

\subsection{Understanding the direct role of dry forests in food and nutrition}

- How do dry forests outside of Africa support rural livelihoods and food security?

- What is the role of dry forests outside the miombo in direct provisioning of foods?

- What is the evidence that wild food supports better nutrition?

- How do different approaches to management (e.g., PES, CBNRM, state control) affect food security?

- How do gender roles and relations affect food security in dry forests, and how do these differ across regions?

- Which groups rely most on forests for food security, particularly outside Africa?

- How do different conservation or development policies related to dry forests affect food security?

\subsection{The role of dry forests in livelihoods}

- How do dry forests outside of Africa support rural livelihoods and food security?

- Which groups rely most on forests for livelihoods, particularly outside Africa?

- How can people be enabled to capture more of the benefits of forest products? For example, how can processing and value addition be made accessible to the poor?

- Are any existing products underused or are there any resources from dry forests that have the potential to be developed into new market products? (Although most efforts to develop novel products from the forest have not been very successful, these were concentrated in southern Africa, and there may be greater potential elsewhere that has not yet been investigated fully.)

- What are the opportunity costs involved in developing the main land-use options in each region (e.g. how do the returns from tourism compare with those from plantation forests), and which factors influence these costs?

- What are the key products of value from each dry forest region and what scope do these products have to alleviate poverty in the areas in which they are found?

- In areas where timber and NTFP production seems unlikely to be able to alleviate poverty, how else can the forest contribute to economic development?

- How do the needs and demands of both humans and forestry systems change as societies change? (For example, how do the demands on forest change with levels of poverty, equity, urbanization, etc.?)

- How do dry forests differ from other forest types in their use, users and value?

\subsection{The need to accurately assess environmental services}

- What services and products do forests in dry regions offer beyond timber (e.g. biodiversity, NTFPs, carbon)?

- How do the services provided by dry forests differ from those provided by other forest types?

- What are the existing methodologies for assessing environmental services, and what are the merits and drawbacks of each?

- Are there methodologies that are particularly relevant to dry forests?

- What research is needed in other themes or disciplines to support this research?

- How do the types of service provided and the potential to provide further services differ between the regions?

\section{Theme 3: Demand for energy}

- What are the regional trends in global supply and demand for woodfuel, charcoal and biofuels and how will these affect dry forests?

- To what extent are forests already incorporated into energy policies, and what is the impact of this on dry forests?

- How will forest policy need to adapt if access to energy is adopted into the successors to the Millennium Development Goals?

- Are there management techniques that can maximize delivery of energy from the forest, and what are the potential impacts of such techniques on other goals such as conservation?

- What alternatives are available to woodfuel and charcoal, and what are the barriers to adoption? What are the benefits and drawbacks?

\section{Theme 4: Sustainable management of dry forests}

\subsection{Improving management techniques for dry forests \\ - Are there technical guidelines that can be developed for management or organizational techniques applicable to specific areas? (For}


example, a guide to developing sustainable forestry in Latin America.)

- Are there techniques or lessons from other forests (dry or not) that would broadly be applicable to improving management of dry forests? For example, what are the key factors in success or failure of community forest schemes? How do these differ between dry forest regions?

- How can biodiversity conservation be incentivized in dry forests, given the relatively low level of productivity that characterizes many dry forests?

- What are the issues in producing dry forest products efficiently and in a way that minimizes impact on the forest while delivering consistent, market-level quality?

- How do different management systems affect production quality, efficiency, sustainability, poverty alleviation and biodiversity potential of dry forest products?

\section{Theme 5: Polices and institutional support for sustainable management}

\subsection{Policies and regulation that influence forests}

- Who/what influences forestry policy in each location and what are the implications for policy reform?

- How do regions differ in terms of the type of institution that enables sustainable management?

- How can institutions be built so that they can respond flexibly to changes in economic and climatic conditions?

- How do policies in other sectors such as trade or climate change affect forests?

- How do labor markets and input markets affect the ability of dry forest managers to profit from forestry?

- What are the key "quick win" issues in the forestry sectors in each region (e.g. lack of capacity, contradictory policy) that could be prioritized for improvement?

- What trade-offs are associated with different policy objectives, and how can these be managed?

- What limits the potential of policy to influence productivity, sustainability and profitability of forest use? Does this differ between dry forests and other forest types?

- How can policy implementation and compliance be improved in the absence of effective state control?

\subsection{Alternative institutions for conservation and management of dry forests}

- What alternative approaches are being implemented in dry forest regions? How do these vary across regions?

- What potential benefits do different management systems in dry regions offer local people, and how do these differ between regions?

- Are there specific institutions or approaches that work particularly well or poorly for dry forests?

- What political or socioeconomic differences and similarities between dry forest regions will affect the relevance of different approaches?

- Which aspects of successful conservation and management systems are transferrable to other areas, and which are context-specific? How will this inform policy?

- Who are the winners and losers under each management institution, and how does this influence their success?

- Are there commonalities between dry forest regions in terms of their development or conservation potential, and how can this inform the debate?

- How can platforms be developed to assist local users to articulate their needs, especially the poor and disadvantaged?

- How do the rights and values of local people differ between dry forest regions, and what are the implications for production forests?

- How can local involvement in production forests improve outcomes for managers? (For example, can local involvement benefit productivity or monitoring?)

- What are the risks in benefit/management sharing and how can these be minimized?

\subsection{Support for small-scale business and trade}

- What are the key small-scale enterprises in dry forest areas, particularly in dry forests outside Africa?

- What are the key constraints to improving profitability within these enterprises?

- How can poor producers/collectors be enabled to add value to raw forest products?

- What are the risks to sustainability when the profitability and marketization of forest products increase?

- How do interactions of market forces such as commodity prices, labor prices, access to markets and input availability affect productivity and sustainability of forest enterprises? 
- What are the drivers for investment in forest enterprises, and how are these affected by competing uses of dry forest lands?

\subsection{The impact of global trade and investment}

- How are trade and investment trends expected to develop in dry forests in coming years, and what can be learned from prominent historical trends (such as the biofuels bubble)?

- Who are the stakeholders in the most important trade relationships and what are the implications of their involvement?

- What are the merits and drawbacks of different management and harvesting regimes for timber and other forest products in each region?

- What factors influence investment in forestry and other industries in forest areas? How do these differ between regions?

- How do non-forestry trends (mineral extraction, services sector, etc.) affect dry forest health and value, and how do the effects differ between regions?

- How do different dry forest products (or products that can be produced in dry forest areas) such as timber, honey or Jatropha compare in terms of employment and environmental impact?

- How do current and future investment trends (biofuels, PES, land acquisition) affect pressure on and value of dry forests?

- How do different legal and socioeconomic systems affect investment trends and outcomes in dry forest countries and regions?

- Who/what influences trade and investment policy and regulation in dry forests, and what are the consequences?

- What are the drivers for investment in forest enterprises/forested land, and how are these affected by competing uses of dry forest lands?

- How do the interactions of market forces, such as commodity prices, labor prices, access to markets and input availability, affect productivity and sustainability of forest enterprises? 


\section{Annex 2: Studies with merit for replication elsewhere}

This Annex sets out some specific studies that would be worth replicating elsewhere in order to build up comparable data or to expand the body of knowledge on dry forests generally. In selecting the studies, usually the approach or the end results/data were considered, rather than methodological specifics.

\section{Land use change}

Redo et al. (2012) conducted a study on the dynamics of land-use change in different agricultural regimes in the dry forests of Brazil and found that crop choice had an impact on deforestation. Similar studies in other regions would be very valuable in improving deforestation projections and in policy making.

\section{General dry forest research}

Sánchez-Azofeifa et al. (2005) explained that the TROPI-DRY program set up several permanent field sites for monitoring dry forests in Latin America. A similar network of sites across other dry forest regions would be extremely valuable in providing reliable time-series data, which are often lacking for dry forests. The concept of the TROPI-DRY network is "to understand and integrate our biological knowledge of tropical dry forests with the social and ecological drivers that determine their change. The TROPI-DRY network was created ... to bring together researchers in conservation biology, ecology, remote sensing, and social sciences to develop a comprehensive, 'state-of-the-art' understanding and explanation of the structure, functioning, and dynamics of tropical dry forest ecosystems" (SánchezAzofeifa et al. 2005, 2). TROPI-DRY functions only in the Americas, and expansion of the network or creation of similar networks in the other regions could improve both understanding and the profile of dry forests. More information is available at http:// tropi-dry.eas.ualberta.ca/about.html.

\section{Comparison studies}

German et al. (2011a) conducted a comparative study across regions looking at social, environment and governance issues related to biofuels in forest areas. Although this study included dry forests, it did not focus on dry forests specifically. Nevertheless, the concept of such a comparison study is useful; more studies of this type, but oriented toward dry forests, would be useful for many of CIFOR's research themes.

\section{Food security}

In what might serve as a valuable template study, do Nascimento et al. (2011) investigated the nutritional value of wild foods used in the Caatinga region of Brazil and concluded that several of the foods were nutritious enough to have potential for improving nutrition in the region. Greater research into the actual nutritional quality and consumption levels of wild food is required in all regions, and more studies of this type would serve to fill this gap. 


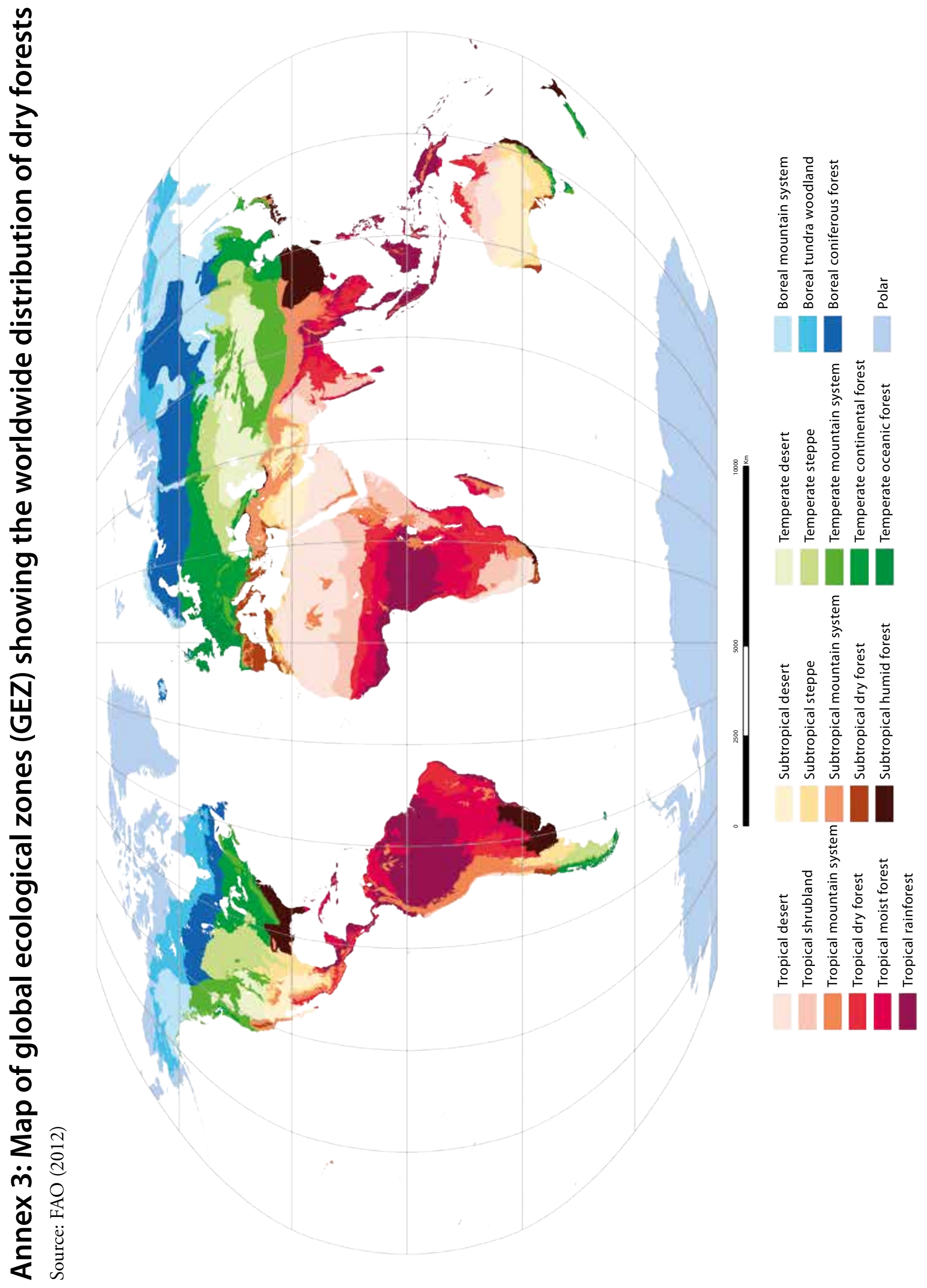



This research was carried out by CIFOR as part of the CGIAR Research Program on Forests, Trees and Agroforestry (CRP-FTA). This collaborative program aims to enhance the management and use of forests, agroforestry and tree genetic resources across the landscape from forests to farms. CIFOR leads CRP-FTA in partnership with Bioversity International, CATIE, CIRAD, the International Center for Tropical Agriculture and the World Agroforestry Centre. 